\title{
OPEN Toxic element levels in ingredients and commercial pet foods
}

\author{
Rafael Vessecchi Amorim Zafalon ${ }^{1}$, Raquel Silveira Pedreira ${ }^{2}$, \\ Thiago Henrique Annibale Vendramini ${ }^{1}$, Mariana Fragoso Rentas ${ }^{1}$, \\ Vivian Pedrinelli ${ }^{1}$, Roberta Bueno Aires Rodrigues ${ }^{1}$, Larissa Wunsche Risolia ${ }^{1}$, \\ Mariana Pamplona Perini ${ }^{1}$, Andressa Rodrigues Amaral ${ }^{1}$, Júlio Cesar de Carvalho Balieiro ${ }^{1}$, \\ Cristiana Fonseca Ferreira Pontieri² \& Marcio Antonio Brunetto ${ }^{1 \bowtie}$
}

Nowadays, there is a growing concern about contamination of toxic metals (TM) in pet food due to the great potential for health risks of these elements. TM concentrations in commercial pet foods $(n=100)$ as well as in ingredients used in their composition $(n=100)$ were analyzed and compared to the Food and Drug Administration (FDA) maximum tolerable level (MTL), and the TM concentrations found in the different sources of carbohydrate, protein, and fat were compared. The TM concentrations were determined by inductively coupled plasma with optical emission spectrometry (ICP-OES). Concentrations above the MTL for aluminum, mercury, lead, uranium, and vanadium were observed in both dog and cat foods, and the percentage of dog foods that exceeded the MTL of these TM were: $31.9 \% ; 100 \% ; 80.55 \% ; 95.83 \%$; and $75 \%$, respectively, and in cat foods: $10.71 \% ; 100 \% ; 32.14 \%$; 85.71\%; $28.57 \%$, respectively. The MTL values of these TMs and the mean values in dog foods ( $\mathrm{mg} / \mathrm{kg}$ dry matter basis) (MTL [mean \pm standard deviation]) were: aluminum: 200 (269.17 \pm 393.74$)$; mercury: 0.27 ( $2.51 \pm 1.31)$; lead: 10 (12.55 \pm 4.30$)$; uranium: 10 (76.82 \pm 28.09$)$; vanadium: 1 (1.35 \pm 0.69$)$, while in cat foods were: aluminum: $200(135.51 \pm 143.95)$; mercury: $0.27(3.47 \pm 4.31)$; lead: $10(9.13 \pm 5.42)$; uranium: 10 (49.83 \pm 29.18$)$; vanadium: $1(0.81 \pm 0.77)$. Dry foods presented higher concentrations of most TM $(P<0.05)$ than wet foods $(P<0.05)$. Among the carbohydrate sources, there were the highest levels of all TM except cobalt, mercury, and nickel in wheat bran $(P<0.05)$, while among the protein sources, in general, animal by-products had higher TM concentrations than plant-based ingredients. Pork fat had higher concentrations of arsenic, mercury, and antimony than fish oil and poultry fat. It was concluded that the pet foods evaluated in this study presented high concentrations of the following TM: aluminum, mercury, lead, uranium, and vanadium.

Toxic metals contamination is a current concern worldwide due to its toxicity, intrinsic persistence, non-biodegradable nature, and cumulative characteristics ${ }^{1,2}$. It is known that toxic metals occur naturally in the environment, but their presence is mainly due to anthropic action, such as agricultural activity, which includes the application of fertilizers and soil amendments; industrial activity, related to mining and metal smelting; and burning of fossil fuels, as well as the incineration of residues and products containing toxic metals ${ }^{3-6}$. Therefore, industrialization, urbanization, population growth, and agriculture are causes of pollution by toxic metals worldwide ${ }^{2,7}$.

The soil is the most important environmental compartment and functions as a deposit for these elements, and can suffer contamination through several sources such as agricultural fertilizers; soil correctives; agrochemicals; irrigation water, sewage sludge, and other waste; atmospheric deposition of industrial sources; and urban emissions ${ }^{8}$. This contamination can reach areas of agricultural production and farm animals, which can have their products and by-products used in the manufacture of pet foods. In the literature, there are several studies conducted in different countries that have found toxic metal contamination with a wide range of concentrations in various types of food intended for humans such as fish, rice, vegetables, dried fruits, meat, quail meat, and bovine tissues ${ }^{9-20}$. Therefore, plant-based ingredients used by the pet food industry grown in contaminated soil, such as corn, rice, wheat, peas, barley, and sorghum, can accumulate toxic metals and contribute to pet food contamination. In the case of food animals, they can accumulate toxic metals when consuming contaminated foods due to soil contamination thus contaminating animal by-products, such as poultry by-products meal

${ }^{1}$ School of Veterinary Medicine and Animal Science, University of São Paulo, 225, Duque de Caxias Norte Avenue, Pirassununga, São Paulo 13635 900, Brazil. ${ }^{2}$ Nutritional Development Center of Premier Pet, Dourado, Brazil. ${ }^{凶}$ email: mabrunetto@usp.br 
and meat meal, which can also contribute to pet food contamination. There is also contamination of rivers and oceans, affecting aquatic organisms that can also be used as raw material by the pet food industry. Therefore, there is great concern about the occurrence of toxic metals in pet food.

Several studies reported the toxic metals presence in canine samples of blood ${ }^{21,22}$, hair ${ }^{21,23-26}$, kidneys ${ }^{27,28}$, bone tissue ${ }^{29}$, and liver ${ }^{23,27,28}$ and hair samples from cats ${ }^{24}$. It is known that ingestion through food is the main contamination route ${ }^{30-33}$, therefore, it is believed that the food consumed by these animals may be contaminated by these elements, which can imply health risks for dogs and cats.

According to Instituto Pet Brasil ${ }^{34}$, the domiciled dog and cat population in Brazil was estimated at 54.2 and 23.9 million, respectively. According to the Brazilian Institute of Geography and Statistics (IBGE) ${ }^{35}, 44.3 \%$ of the 65 million households have at least one dog and $17.7 \%$ at least one cat. The increase of the population of domiciled dogs and cats, as well as the intensification of the relationship between owners and their pets, is reflected in the expansion of the pet market in general, including the food segment. According to data from the Brazilian Association of the Pet Products Industry (ABINPET) ${ }^{36}$, the Brazilian pet market turnover in 2018 was R\$ (Brazilian real) 22.3 billion (US\$ 6.16 billion), which places Brazil as the third largest in the world, representing more than $4.7 \%$ of the global turnover in this segment. The pet food market represents $73.3 \%$ of this revenue, and it was the segment of the pet market that grew the most between 2018 and 2019 (8.4\%), with a production of around 2.85 million tons ${ }^{36}$.

The concern about the safety of commercial dog and cat food is growing, since the food recall that occurred in the U.S. due to melamine contamination, which resulted in the death of thousands of dogs from acute kidney failure ${ }^{37,38}$. Recently, the pet food industry has diversified the variety of its products, with different types of ingredients, such as additives to reduce fecal odor and alternative sources of protein and carbohydrate, like vegan or grain-free diets; and processing methods, such as wet foods, which may include cheaper ingredients of lower quality and can result in the introduction of several contaminants, such as pesticides, mycotoxins, and toxic metals ${ }^{38,39}$.

To date, some studies have evaluated the presence of toxic metals in commercial pet foods ${ }^{38,40-46}$ and ingredients used by the pet food industry ${ }^{47-49}$. From the published data, the high aluminum concentrations in commercial pet foods observed in the studies by Fernandes ${ }^{38}$, da Costa ${ }^{45}$, and Paulelli ${ }^{46}$ stand out, in which aluminum concentrations up to $11,900 \mathrm{mg} / \mathrm{kg}$ food were observed, which correspond to 59.5 times the maximum limit established for these species. In small animals, the possible adverse effects associated with consuming this amount of aluminum are unclear. It is also worth highlighting the lead concentrations found in the study by Duran ${ }^{40}$, in which concentrations above the established limit for dogs and cats were observed. These results are considered worrying, as an excessive lead consumption has been associated with gastrointestinal signs ${ }^{50,51}$, neurological disorders ${ }^{50,52}$, damage to the hematopoietic system ${ }^{53,54}$, and kidney injuries ${ }^{52}$.

Given the relevance of the topic and the little information in the literature about toxic metal contamination in pet foods, and especially in ingredients, the goals of this study were: to evaluate the concentrations of toxic metals [aluminum (Al), antimony ( $\mathrm{Sb})$, arsenic (As), barium $(\mathrm{Ba})$, beryllium $(\mathrm{Be})$, boron $(\mathrm{B})$, cadmium $(\mathrm{Cd})$, chromium $(\mathrm{Cr})$, cobalt $(\mathrm{Co})$, iron $(\mathrm{Fe})$, lead $(\mathrm{Pb})$, mercury $(\mathrm{Hg})$, nickel $(\mathrm{Ni})$, selenium $(\mathrm{Se})$, tin $(\mathrm{Sn})$, uranium $(\mathrm{U})$, and vanadium $(\mathrm{V})$ ] in ingredients used in pet food formulation and in commercial pet foods available in the Brazilian market; to compare the results with the maximum tolerated level values recommended for dogs and cats; to investigate whether there is a difference between the toxic metals' concentrations in dry and wet foods and between the different categories (economical, premium, and super premium); to analyze if there is a difference between toxic metals concentrations in dog and cat foods and to evaluate if there is a difference between protein sources and carbohydrate sources.

\section{Material and methods}

Acquisition of samples. A total of 100 complete and balanced commercial pet foods for adult animals from 29 different manufacturers were purchased from pet shops located in cities of the State of São Paulo (São Carlos, Araraquara, and Indaiatuba) during the period from 09/03/2018 to 01/25/2019. The number of samples of each food type is shown in Table 1 . The ingredient samples were supplied by the company Premier Pet, during the period from $09 / 05 / 2018$ to $04 / 25 / 2019$, and each sample of each ingredient is from a different supplier. A total of $500 \mathrm{~g}$ of sample of each ingredient were collected, taken from different points of the load. The ingredients analyzed in this study are listed in Table 2 . The dry foods were classified into the following categories: standard, premium, and super premium. This classification was carried out based on information declared by the manufacturer on the labels of the commercial products, which is a commercial classification. The standard products are formulated with the lowest cost, with lower concentrations of nutrients such as protein and fat generally, with values close to the minimum recommendations. Premium foods, in turn, have a better selection of ingredients and higher nutrient concentrations. Finally, the super premium foods have high-quality ingredients in their formulation, providing a more adequate nutrition and may even incorporate functional ingredients.

Dry matter analysis. The samples of each dry food were ground in a Willye knife mill (Marconi MA340, Piracicaba, Brazil) (sieve of $1 \mathrm{~mm}$ ). The wet food samples were previously dehydrated in a forced circulation oven at $55^{\circ} \mathrm{C}$ for $72 \mathrm{~h}^{55}$, and later were ground in an analytical mill (Ika, A11 Basic Mill, Staufen, Germany). The samples of broken rice, whole corn, soybean meal, and wheat bran had to be milled in a micro-knife mill (Marconi MA048, Piracicaba, Brazil) (sieve of $1 \mathrm{~mm}$ ).

After grinding, a sub-sample was taken for dry matter (DM) analysis in an oven at $105^{\circ} \mathrm{C}^{56}$. These analyses were performed in duplicate at the Multiuser Laboratory of Animal Nutrition and Bromatology of the Department of Nutrition and Animal Production of the School of Veterinary Medicine and Animal Science of University 


\begin{tabular}{|l|l|}
\hline Commercial pet foods & No. of samples \\
\hline Dog foods & 72 \\
\hline Standard dry foods & 18 \\
\hline Premium dry foods & 23 \\
\hline Super premium dry foods & 20 \\
\hline Wet foods & 11 \\
\hline Cat foods & 28 \\
\hline Standard dry foods & 4 \\
\hline Premium dry foods & 5 \\
\hline Super premium dry foods & 5 \\
\hline Wet foods & 14 \\
\hline Total & 100 \\
\hline
\end{tabular}

Table 1. Number of samples of each type of commercial pet food analyzed.

\begin{tabular}{|l|l|}
\hline Ingredients & No. of samples \\
\hline Animal by-products & 54 \\
\hline Chicken by-products meal & 16 \\
\hline Beef meal & 8 \\
\hline Fish meal & 6 \\
\hline Feather meal & 6 \\
\hline Fish oil & 6 \\
\hline Pork fat & 6 \\
\hline Poultry fat & 6 \\
\hline Plant-based ingredients & 40 \\
\hline Broken rice & 6 \\
\hline Whole corn & 10 \\
\hline Wheat bran & 6 \\
\hline Soybean meal & 6 \\
\hline Corn gluten meal 21 & 6 \\
\hline Corn gluten meal 60 & 6 \\
\hline Mineral supplement & 6 \\
\hline Total & 100 \\
\hline
\end{tabular}

Table 2. Analyzed ingredients and number of samples per ingredient.

of Sao Paulo, Pirassununga-Brazil. Repetition was performed when the variation coefficient between samples was greater than $5.0 \%$.

Sample preparation for the toxic metal's determination. The preparation of all samples (except samples of fat sources) was carried out by the wet method according to Pedrinelli ${ }^{57}$. For all samples, $0.5 \mathrm{~g}$ were weighed and placed in polypropylene tubes, and afterward, $1.5 \mathrm{~mL}$ of $\mathrm{HNO}_{3}$ P.A. $(65 \% \mathrm{~m} / \mathrm{v})$ (brand: Synth $\left.{ }^{\circ}\right)$ (Diadema, Brazil) and $2.0 \mathrm{~mL}$ of $\mathrm{H}_{2} \mathrm{O}_{2}(30 \% \mathrm{~m} / \mathrm{v})$ (brand: Dinâmica ) (Indaiatuba, Brazil) were added to each tube. After $30 \mathrm{~min}$, the volume was completed with $4.5 \mathrm{~mL}$ of ultrapure water type $\mathrm{I}(18.2 \mathrm{M} \Omega \mathrm{cm}$ resistivity; conductivity: $0.054 \mu \mathrm{S} / \mathrm{cm}$; TOC: $<5$ PPB $[<5 \mu \mathrm{g} / \mathrm{L}]$ ), obtained from a Milli-Q purification system (Millipore, USA). Then, the tubes were placed in a microwave oven (Multiwave GO, Anton Paar, Austria) and were subjected to heating in two phases: in the first, the samples were heated for $20 \mathrm{~min}$ until reaching $180{ }^{\circ} \mathrm{C}$ in $400 \mathrm{~W}$; in the second phase, the samples were heated by $180{ }^{\circ} \mathrm{C}$ at $800 \mathrm{~W}$ for $10 \mathrm{~min}$ and, subsequently, cooling was performed for $10 \mathrm{~min}$. After the digestion procedure, the samples were transferred to polyethylene tubes and ultrapure water type I (18.2 M $\Omega \mathrm{cm}$ resistivity; conductivity: $0.054 \mu \mathrm{S} / \mathrm{cm}$; TOC: $<5 \mathrm{PPB}[<5 \mu \mathrm{g} / \mathrm{L}])$, obtained from a Milli-Q purification system (Millipore, USA), was added until they reached $25 \mathrm{~mL}$ of volume. Blank solutions were subjected to the same procedure to verify the quality of the reagents. The procedure was performed in duplicate. The samples' preparation by microwave digestion was carried out in the Laboratory of Biorigin Brazil (Lençóis Paulista, Brazil).

The preparation of the fat samples was performed using the methodology adapted from Llorent-Martínez ${ }^{58}$. Acid digestion of samples was carried out in a microwave SW-4 model Speed Wave (Berghof, Germany). An aliquot of approximately $0.15 \mathrm{~g}$ of sample was weighed directly into the digestion vessel, then $5 \mathrm{~mL}$ of diluted $\mathrm{HNO}_{3}\left(25 \% \mathrm{HNO}_{3}\right.$ and $75 \%$ ultrapure water) was added to each oil sample. The $\mathrm{HNO}_{3}$ used was P.A. (65\% m/v) 


\begin{tabular}{|l|l|}
\hline Parameter & Characteristics \\
\hline Radiofrequency power $(\mathrm{kW})$ & 1.2 \\
\hline Plasma gas flow rate $(\mathrm{L} / \mathrm{min})$ & 10 \\
\hline Auxiliary gas flow rate $(\mathrm{L} / \mathrm{min})$ & 0.6 \\
\hline Sample uptake rate $(\mathrm{s})$ & 30 \\
\hline Nebulizer gas flow rate $(\mathrm{L} / \mathrm{min})$ & 0.7 \\
\hline Nebulizer type & Concentric \\
\hline Spray chamber & Cyclone \\
\hline Replicates & 2 \\
\hline
\end{tabular}

Table 3. Operational conditions of inductively coupled plasma optical emission spectrometry (ICP-OES) with axial configuration.

(brand: Synth ${ }^{\circ}$ (Diadema, Brazil), and ultrapure water used was a type I (18.2 $\mathrm{M} \Omega \mathrm{cm}$ resistivity; conductivity: $0.054 \mu \mathrm{S} / \mathrm{cm}$; TOC: $<5$ PPB [<5 $\mu \mathrm{g} / \mathrm{L}]$ ), obtained from a Milli-Q purification system (Millipore, USA). Subsequently, the digestion procedure was performed in four stages of heating. First, the samples were heated for $5 \mathrm{~min}$ until reaching $90^{\circ} \mathrm{C}$ at $700 \mathrm{~W}$. In the second stage, the temperature was maintained at $90{ }^{\circ} \mathrm{C}$ for 3 min at $600 \mathrm{~W}$. In the third stage, the temperature was increased for $10 \mathrm{~min}$ to $170^{\circ} \mathrm{C}$ at $600 \mathrm{~W}$. In the last stage, the temperature was kept at $170{ }^{\circ} \mathrm{C}$ for another $7 \mathrm{~min}$ at $600 \mathrm{~W}$. After this stage, the samples were cooled and ultrapure water was added until the volume reached $15 \mathrm{~mL}$. Two blank solutions were included for every 18 fat samples. The digestion of fat samples was carried out at the analytical center of the chemistry institute of the State University of Campinas (Campinas, Brazil).

Determination of elements in ICP-OES. The determination of aluminum ( $\mathrm{Al}$ ), antimony (Sb), arsenic (As), barium (Ba), beryllium (Be), boron (B), cadmium (Cd), chromium $(\mathrm{Cr})$, cobalt (Co), iron (Fe), lead (Pb), mercury $(\mathrm{Hg})$, nickel $(\mathrm{Ni})$, selenium $(\mathrm{Se})$, tin $(\mathrm{Sn})$, uranium $(\mathrm{U})$, and vanadium $(\mathrm{V})$ was performed by optical emission spectrometry with inductively coupled plasma [ICP-OES (ICPE-9000, Shimadzu of Brazil, Barueri, Brazil)], at the Multiuser Laboratory of Animal Nutrition and Bromatology of the Department of Nutrition and Animal Production of the School of Veterinary Medicine and Animal Science of the University of Sao Paulo, Pirassununga-Brazil.

For As, Hg, Sb, and Se determination a hydride generator (hydride ICP, Elemental Scientific, Omaha, USA) coupled to the ICP-OES was used. To avoid cross-contamination, ultrapure water type I $(18.2 \mathrm{M} \Omega \mathrm{cm}$ resistivity; conductivity: $0.054 \mu \mathrm{S} / \mathrm{cm}$; TOC: $<5$ PPB $[<5 \mu \mathrm{g} / \mathrm{L}]$ ), obtained from a Milli-Q purification system (Millipore, USA) was used between the samples to clean the system and, for every five analyses of samples determined by the ICP-OES, the system was cleaned with $1.0 \mathrm{~g} / 100 \mathrm{~mL}$ nitric acid P.A. (65\% m/v) (brand: Synth ) (Diadema, Brazil). The calibration curves were prepared using multi-element solutions with a certificate of analysis and traceability to NIST (National Institute of Standards and Technology, Gaithersburg, MD, USA) of $100 \mathrm{mg} / \mathrm{L}$ for the elements $\mathrm{Al}, \mathrm{As}, \mathrm{B}, \mathrm{Ba}, \mathrm{Be}, \mathrm{Cd}, \mathrm{Co}, \mathrm{Cr}, \mathrm{Fe}, \mathrm{Hg}, \mathrm{Ni}, \mathrm{Pb}, \mathrm{Sb}, \mathrm{Se}, \mathrm{Sn}$, and $\mathrm{V}$, and monoelementary solutions (with a certificate of analysis and traceability to NIST) of $100 \mathrm{mg} / \mathrm{L}$ of U. The reference material used was SpecSol ${ }^{\circ}$ (Jacareí, Brazil) and was purchased from the company Quimlab (www.quimlab.com.br). The metal concentrations of the reference material are traced to the following NIST standards: Al: NIST 928; As: NIST 3103a; B: NIST 3107; Ba: NIST 3104a; Be: NIST 3105a; Cd: NIST 928; Co: NIST 928; Cr: NIST 3112a; Fe: NIST 928; Hg: NIST 3133; Ni; NIST 928; Pb: NIST 928; Se: NIST 3149; Sb: NIST 136f; Sn: NIST 3161a; U: NIST 3164; V: NIST 3165. The curves were prepared with the aid of automatic pipettes and falcon tubes were used. Calibration curves were prepared one day before analysis. For $\mathrm{As}, \mathrm{Sb}, \mathrm{Se}$, and $\mathrm{Hg}$ the calibration curves had the following points: $0.001-0.05-0.1-0.5-1-2 \mathrm{ppm}$. For the other metals analyzed the calibration curves had the following points: $0.001-0.05-0.1-0.5-1-2-5-10 \mathrm{ppm}$.

The emission line wavelengths of each element were: As-193,759; Sb-206,833; Se-196,090; Hg-184,950; A1-167,081; B-249,773; Ba-455,403; Be-234,861; Cd-226.502; Co-238,892; Cr-205.552; Fe-238,204; $\mathrm{Ni}-231,604 ; \mathrm{Pb}-220,353 ; \mathrm{Sn}-189,989 ; \mathrm{U}-263,553$; and $\mathrm{V}-292,402$. Operational conditions are presented in Table 3.

Statistical analysis. For comparisons between dry and wet food, dog and cat food, categories of dry foods, carbohydrate sources, and protein sources, the Shapiro-Wilk test was performed to assess the normality of the residues and the $\mathrm{F}$ test to verify the homogeneity of the variances. For data that did not show a normal distribution, the generalized linear mixed model with a logarithmic link function was used to stabilize the residues. After data transformation, ANOVA was performed and, when there was a difference between the groups, the Tukey test was performed. The analyses described above were performed using the Statistical Analysis System (SAS) software version 9.4 (SAS Institute, North Carolina, USA) and p values below 0.05 were considered significant.

The results found in commercial foods were compared with the MTLs established by the FDA ${ }^{59} \mathrm{in} \mathrm{mg} / \mathrm{kg}$ of dry matter, descriptively. For the elements whose values were not indicated by $\operatorname{FDA}^{59}$ (B, Ba, and Sn), the MTL values of the most sensitive mammal to each of the elements were used, according to the Mineral Tolerance of Animals ${ }^{60}$ and, for iron, the legal limit values of European Union legislation were used, according to regulation $1831 / 2003 / \mathrm{EC}$, expressed in FEDIAF $^{61}$, also in $\mathrm{mg} / \mathrm{kg}$ of dry matter. 


\begin{tabular}{|l|l|l|l|l|c|c|}
\hline Toxic metals & MTL & LL & Mean \pm SD & Minimum-maximum & \% above MTL $(\mathbf{n})$ & \% of samples with detection $(\mathbf{n})$ \\
\hline Aluminum $(\mathrm{Al})$ & $200^{\mathrm{a}}$ & - & $269.17 \pm 393.74$ & $0-2406$ & $31.9(23)$ & $98.6(71)$ \\
\hline Antimony $(\mathrm{Sb})$ & $40^{\mathrm{b}}$ & - & $2.10 \pm 0.48$ & $1.56-4.90$ & $0(0)$ & $100(72)$ \\
\hline Arsenic $(\mathrm{As})$ & $12.5^{\mathrm{b}}$ & - & - & - & $0(0)$ & $0(0)$ \\
\hline Barium $(\mathrm{Ba})$ & $100^{\mathrm{a}}$ & - & $27.12 \pm 21.17$ & $0.38-96.41$ & $0(0)$ & $100(72)$ \\
\hline Beryllium $(\mathrm{Be})$ & $5^{\mathrm{b}}$ & - & - & - & $0(0)$ & $0(0)$ \\
\hline Boron $(\mathrm{B})$ & $150^{\mathrm{a}}$ & - & - & - & $0(0)$ & $0(0)$ \\
\hline Cadmium $(\mathrm{Cd})$ & $10^{\mathrm{b}}$ & - & $2.92 \pm 1.77$ & $0-6.86$ & $0(0)$ & $88.9(64)$ \\
\hline Lead $(\mathrm{Pb})$ & $10^{\mathrm{b}}$ & - & $12.55 \pm 4.30$ & $0-21.82$ & $80.55(58)$ & $97.22(70)$ \\
\hline Cobalt $(\mathrm{Co})$ & $2.5^{\mathrm{b}}$ & - & $1.65 \pm 2.36$ & $0-14.11$ & $6.94(5)$ & $91.67(66)$ \\
\hline Chromium $(\mathrm{Cr})$ & $10^{\mathrm{b}}$ & - & $4.73 \pm 1.20$ & $0.90-7.74$ & $0(0)$ & $100(72)$ \\
\hline Tin $(\mathrm{Sn})$ & $100^{\mathrm{a}}$ & - & $9.88 \pm 1.58$ & $6.63-14.62$ & $0(0)$ & $100(72)$ \\
\hline Iron $(\mathrm{Fe})$ & - & 1420 & $338.64 \pm 213.40$ & $18.56-1367.32$ & $0(0)$ & $100(72)$ \\
\hline Mercury $(\mathrm{Hg})$ & $0.27^{\mathrm{b}}$ & - & $2.51 \pm 1.31$ & $1.11-7.72$ & $100(72)$ & $100(72)$ \\
\hline Nickel $(\mathrm{Ni})$ & $50^{\mathrm{b}}$ & - & $1.67 \pm 0.80$ & $0-3.48$ & $0(0)$ & $93.05(67)$ \\
\hline Selenium $(\mathrm{Se})$ & - & 0.568 & - & - & $0(0)$ & $0(0)$ \\
\hline Uranium $(\mathrm{U})$ & $10^{\mathrm{b}}$ & - & $76.82 \pm 28.09$ & $0-122.05$ & $95.83(69)$ & $95.83(69)$ \\
\hline Vanadium $(\mathrm{V})$ & $1^{\mathrm{b}}$ & - & $1.35 \pm 0.69$ & $0-3.94$ & $75(54)$ & $93.05(67)$ \\
\hline
\end{tabular}

Table 4. Detected toxic metal concentrations ( $\mathrm{mg} / \mathrm{kg} \mathrm{DM})$ in the $72 \mathrm{dog}$ foods evaluated and comparison with the maximum tolerated level established by the FDA (2011) and/or legal limit expressed by FEDIAF (2020).

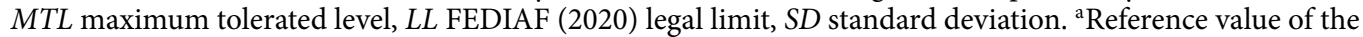
most sensitive mammal according to the National Research Council (2005). ${ }^{b}$ Reference value according to the United States Food and Drug Administration (2011).

For the elements that showed concentrations above the MTL of FDA ${ }^{59}$ or legal limit expressed in FEDIAF ${ }^{61}$, to better investigate whether the values observed in food are a real health issue, it was calculated how much animals would consume of these elements per kg of body weight (BW) per day if they ate these analyzed foods. Thus, a simulation was carried out with dogs of different sizes $(5 \mathrm{~kg}, 15 \mathrm{~kg}, 30 \mathrm{~kg}$, and $50 \mathrm{~kg})$ and, in the case of cats, simulations were carried out with variation in body weight between 3 and $5 \mathrm{~kg}$. Simulations were performed with animals of different sizes, as the daily amounts consumed of the metals were calculated per kg of BW, not per $\mathrm{kg}$ of metabolic weight. Thus, the amount consumed per kg of BW differs, so that the smaller animals consume greater amounts when compared to larger animals.

The maintenance energy requirement for dogs was calculated using the equation $95 \mathrm{kcal} \times \mathrm{BW}^{0.75}$, and for cats, through the equation $100 \mathrm{kcal} \times \mathrm{BW}^{0.67}$. To calculate the daily amount of food to be provided, the metabolizable energy (ME) values declared on the labels of the analyzed foods were used and, for foods that did not contain this information stated on the label, the ME was estimated using the method described by the $\mathrm{NRC}^{62}$.

Ethical approval. The experimental protocol was conducted according to ethical principles in human and animal experimentation and was approved by the Commission on Ethics in the Use of Animals of the School of Veterinary Medicine and Animal Science of the University of Sao Paulo (protocol number 6717110219).

\section{Results}

Toxic metals concentrations in commercial pet foods. Through ICP-OES methodology, it was possible to determine 17 elements. In dog foods, the elements $\mathrm{Sb}, \mathrm{Ba}, \mathrm{Cr}, \mathrm{Sn}, \mathrm{Fe}$, and $\mathrm{Hg}$ were detected in all samples (Table 4). In cat foods, the metals $\mathrm{Cr}, \mathrm{Hg}, \mathrm{Sb}, \mathrm{Fe}$, and $\mathrm{Sn}$ were detected in all samples analyzed (Table 5). In both dog and cat foods, the elements As, B, Be, and Se were below the detection limit of $0.05 \mathrm{mg} / \mathrm{kg}$ in all samples (Tables 4 and 5). Regarding the comparisons of the results with the MTLs by FDA ${ }^{59}$, in dog foods, values above the MTL were observed for the following elements: $\mathrm{Al}, \mathrm{Pb}, \mathrm{Co}, \mathrm{Hg}, \mathrm{U}$, and $\mathrm{V}$. In cat foods, values above MTL were observed for $\mathrm{Al}, \mathrm{Cr}, \mathrm{Hg}, \mathrm{Pb}, \mathrm{U}$, and $\mathrm{V}$. In addition, one food had $\mathrm{Fe}$ concentration above the legal limit.

The number of times that dog and cat foods exceeded the MTL are shown in Figs. 1 and 2, respectively. The percentage of dog foods that exceeded the MTL of TMs were: $31.9 \%(\mathrm{Al}) ; 100 \%(\mathrm{Hg}) ; 80.55 \%(\mathrm{~Pb}) ; 95.83 \%(\mathrm{U})$; and $75 \%(\mathrm{~V})$, respectively, and in cat foods: $10.71 \%(\mathrm{Al}) ; 100 \%(\mathrm{Hg}) ; 32.14 \%(\mathrm{~Pb}) ; 85.71 \%(\mathrm{U}) ; 28.57 \%(\mathrm{~V})$, respectively. Figures 3 and 4 show the quantity (in $\mathrm{mg}$ ) that the analyzed foods provide per $\mathrm{kg}$ of BW of each TM that presented values above the MTL. In the comparison between dry and wet foods, higher concentrations of $\mathrm{Al}$ $(\mathrm{P}<0.0001), \mathrm{Ba}(\mathrm{P}<0.0001), \mathrm{Cd}(\mathrm{P}=0.0008)$, $\mathrm{Co}(\mathrm{P}<0.0001), \mathrm{Cr}(\mathrm{P}=0.0043), \mathrm{Hg}(\mathrm{P}<0.0001), \mathrm{Ni}(\mathrm{P}=0.0014)$, $\mathrm{Pb}(\mathrm{P}<0.0001), \mathrm{U}(\mathrm{P}<0.0001)$, and $\mathrm{V}(\mathrm{P}=0.0011)$ in dry foods were observed, while wet foods had higher Fe concentrations $(\mathrm{P}<0.0001)$ (Table 6).

As for comparisons between dog and cat foods, higher concentrations of $\mathrm{Al}(\mathrm{P}=0.0033), \mathrm{Ba}(\mathrm{P}=0.0116)$, and $\mathrm{Fe}(\mathrm{P}<0.0001)$ in wet dog foods were observed, compared to wet cat foods, which presented higher $\mathrm{U}$ concentrations $(\mathrm{P}=0.0331)$ (Table 7). Dry dog foods had higher concentrations of $\mathrm{Al}(\mathrm{P}<0.0001), \mathrm{Ba}(\mathrm{P}<0.0001), \mathrm{Co}$ $(\mathrm{P}=0.0104)$, and $\mathrm{U}(\mathrm{P}<0.0001)$, than dry cat foods, which presented higher concentrations of $\mathrm{Fe}(\mathrm{P}<0.0001)$ and $\mathrm{Hg}(\mathrm{P}<0.0001)$ (Table 8). Regarding the comparisons between the different dog food categories, the standard 


\begin{tabular}{|l|l|l|l|l|l|l|}
\hline Toxic metals & MTL & LL & Mean \pm SD & Minimum-maximum & \% above MTL $(\mathbf{n})$ & \% of samples with detection $(\mathbf{n})$ \\
\hline Aluminum $(\mathrm{Al})$ & $200^{\mathrm{a}}$ & - & $135.51 \pm 143.95$ & $0-582.10$ & $10.71(3)$ & $96.43(27)$ \\
\hline Antimony $(\mathrm{Sb})$ & $40^{\mathrm{b}}$ & - & $2.38 \pm 1.21$ & $1.68-6.08$ & $0(0)$ & $100(28)$ \\
\hline Arsenic $(\mathrm{As})$ & $12.5^{\mathrm{b}}$ & - & - & - & $0(0)$ & $0(0)$ \\
\hline Barium $(\mathrm{Ba})$ & $100^{\mathrm{a}}$ & - & $10.80 \pm 10.68$ & $0-30.15$ & $0(0)$ & $96.43(27)$ \\
\hline Beryllium $(\mathrm{Be})$ & $5^{\mathrm{b}}$ & - & - & - & $0(0)$ & $0(0)$ \\
\hline Boron $(\mathrm{B})$ & $150^{\mathrm{a}}$ & - & - & - & $0(0)$ & $0(0)$ \\
\hline Cadmium $(\mathrm{Cd})$ & $10^{\mathrm{b}}$ & - & $2.18 \pm 1.39$ & $0-6.34$ & $0(0)$ & $89.29(25)$ \\
\hline Lead $(\mathrm{Pb})$ & $10^{\mathrm{b}}$ & - & $9.13 \pm 5.42$ & $0-25.75$ & $32.14(9)$ & $92.86(26)$ \\
\hline Cobalt $(\mathrm{Co})$ & $2.5^{\mathrm{b}}$ & - & $0.66 \pm 0.69$ & $0-2.49$ & $0(0)$ & $82.14(23)$ \\
\hline Chromium $(\mathrm{Cr})$ & $10^{\mathrm{b}}$ & - & $3.90 \pm 1.75$ & $0.87-10.22$ & $3.57(1)$ & $100(28)$ \\
\hline Tin $(\mathrm{Sn})$ & $100^{\mathrm{a}}$ & - & $9.56 \pm 2.18$ & $3.96-13.98$ & $0(0)$ & $100(28)$ \\
\hline Iron $(\mathrm{Fe})$ & - & 1420 & $383.05 \pm 344.87$ & $21.39-1871.16$ & $3.57(1)$ & $100(28)$ \\
\hline Mercury $(\mathrm{Hg})$ & $0.27^{\mathrm{b}}$ & - & $3.47 \pm 4.31$ & $1.20-18.87$ & $100(28)$ & $100(28)$ \\
\hline Nickel $(\mathrm{Ni})$ & $50^{\mathrm{b}}$ & - & $1.13 \pm 1.33$ & $0-4.94$ & $0(0)$ & $78.57(22)$ \\
\hline Selenium $(\mathrm{Se})$ & - & 0.568 & - & - & $0(0)$ & $0(0)$ \\
\hline Uranium $(\mathrm{U})$ & $10^{\mathrm{b}}$ & - & $49.83 \pm 29.18$ & $0-111.94$ & $85.71(24)$ & $96.43(27)$ \\
\hline Vanadium $(\mathrm{V})$ & $1^{\mathrm{b}}$ & - & $0.81 \pm 0.77$ & $0-2.87$ & $28.57(8)$ & $78.57(22)$ \\
\hline
\end{tabular}

Table 5. Detected toxic metals concentrations ( $\mathrm{mg} / \mathrm{kg} \mathrm{DM})$ in the 28 cat foods evaluated and comparison with the maximum tolerated level of the FDA (2011) and/or legal limit expressed by FEDIAF (2020). MTL

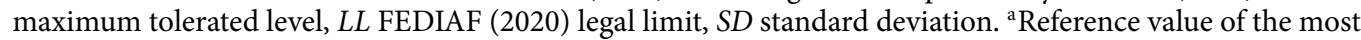
sensitive mammal according to the National Research Council (2005). ${ }^{b}$ Reference value according to the United States Food and Drug Administration (2011).

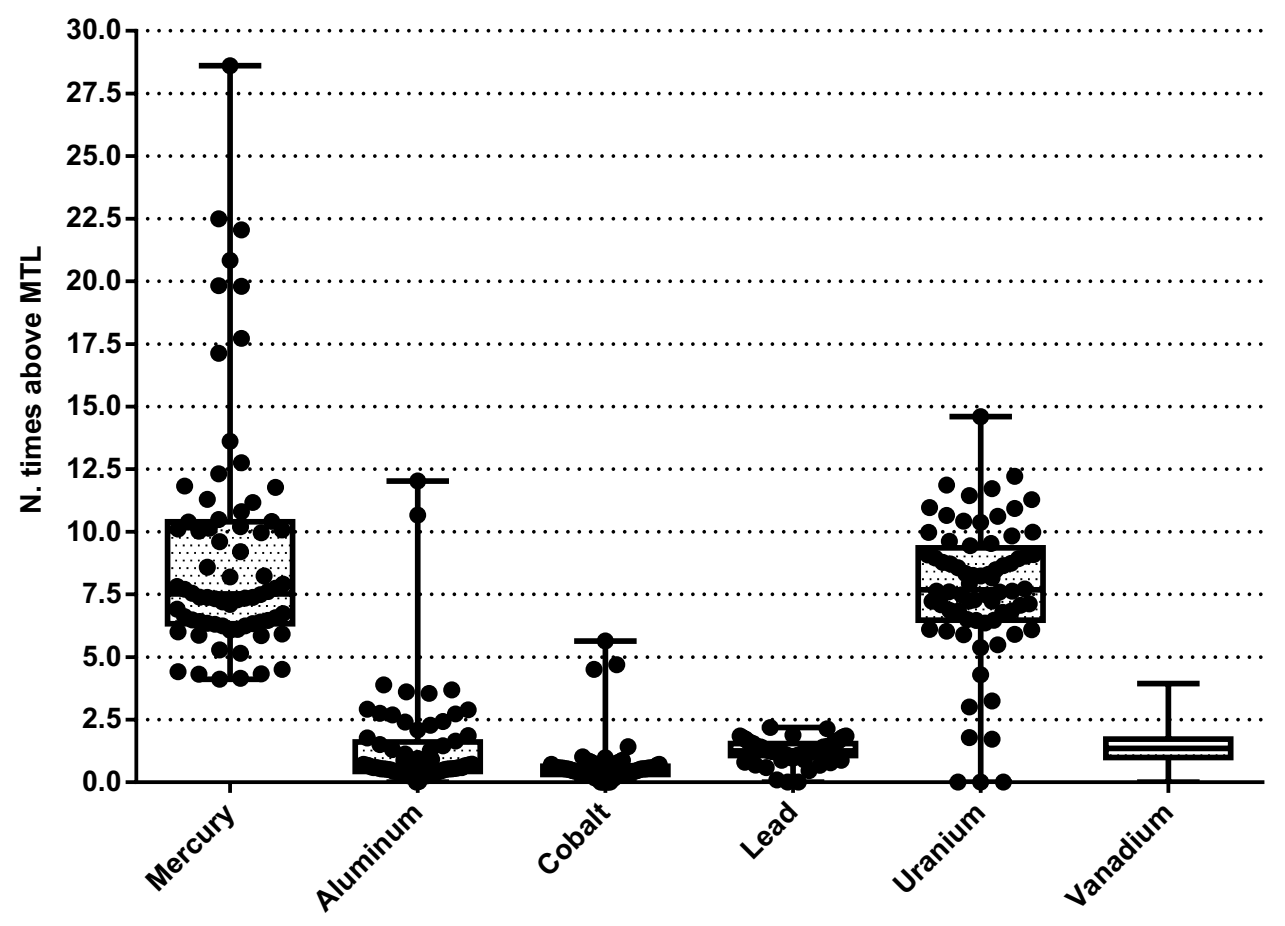

Figure 1. Number of times above the maximum tolerated level (MTL) for toxic metals that had values above that limit, in commercial dog foods.

category had the highest concentrations of $\mathrm{Ba}(\mathrm{P}<0.0001), \mathrm{Fe}(\mathrm{P}<0.0001)$, and $\mathrm{U}(\mathrm{P}<0.0001)$, while the superpremium category showed the highest concentrations of $\mathrm{Al}(\mathrm{P}<0.0001)$ (Table 9$)$. As for this same comparison in cat foods, the premium category showed the highest levels of $U(P=0.0084)$, and the super premium category presented the highest concentrations of $\mathrm{Fe}(\mathrm{P}<0.0001)$. Regarding $\mathrm{Hg}$, the premium category showed higher concentrations than the super premium category $(\mathrm{P}=0.0359)$, and the standard category did not differ from the others (Table 10). 


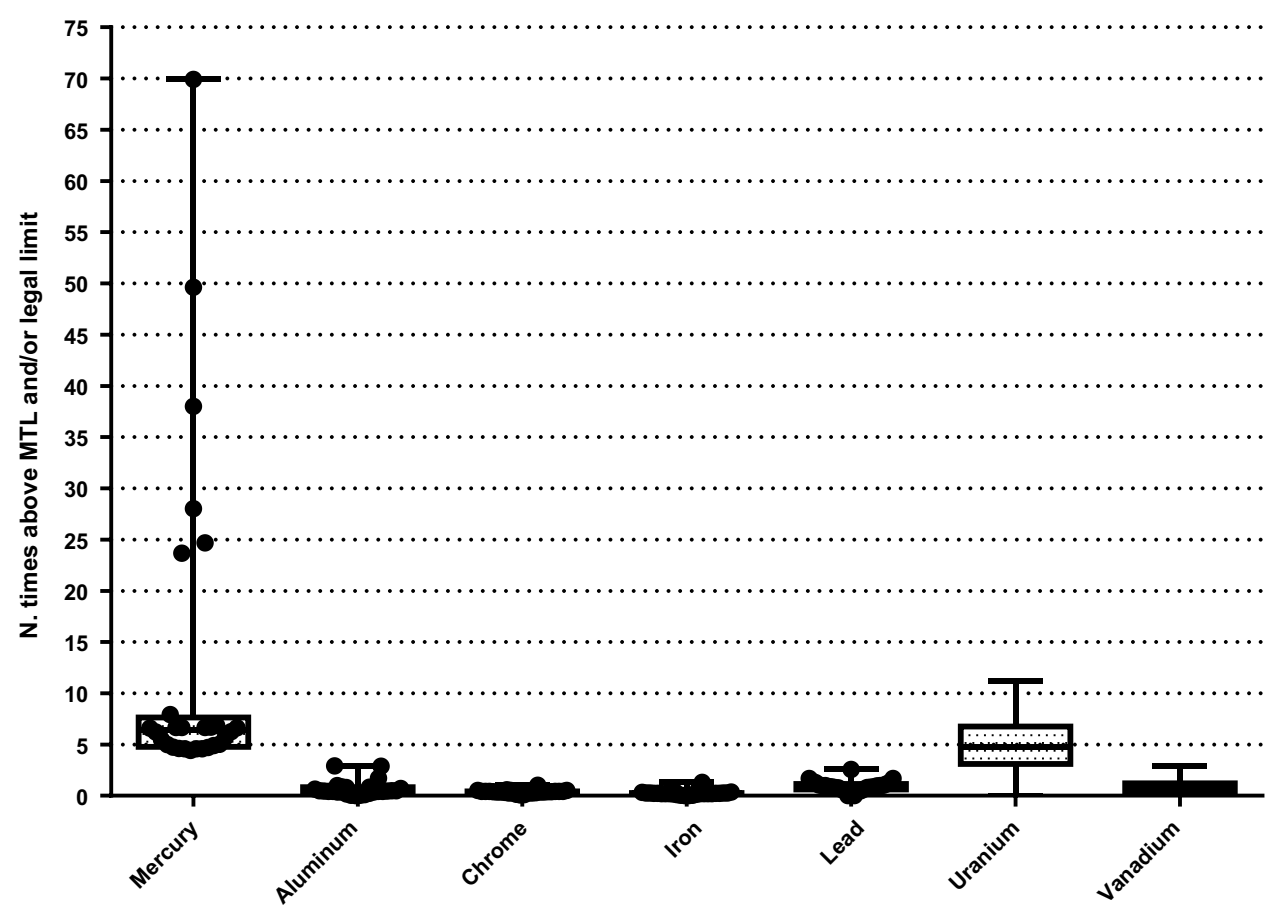

Figure 2. Number of times above maximum tolerated level (MTL) and/or legal limit for toxic metals that had values above that limit, in commercial cat foods.

Toxic metals concentrations in ingredients. Regarding the comparisons between ingredients used as a carbohydrate source, wheat bran showed higher concentrations of $\mathrm{Al}, \mathrm{Ba}, \mathrm{Cr}, \mathrm{Fe}, \mathrm{Pb}, \mathrm{Sn}$, and $\mathrm{U}$, compared to whole corn and broken rice $(\mathrm{P}<0.05)$ (Table 11). Whole corn showed the highest Ni concentrations $(\mathrm{P}=0.0007)$. There was no difference between carbohydrate sources for the other elements analyzed $(\mathrm{P}>0.05)$ (Table 12). As for comparisons between protein sources, there was a difference between the ingredients for most of the elements analyzed $(\mathrm{P}<0.05)$, except for $\mathrm{Co}(\mathrm{P}>0.05)$ (Table 12). Regarding fat sources, only $\mathrm{Al}, \mathrm{As}, \mathrm{Cd}, \mathrm{Fe}, \mathrm{Hg}, \mathrm{Ni}$, $\mathrm{Sb}$, and $\mathrm{Sn}$ were detected in samples of at least one type of ingredient. Pork fat had higher concentrations of As, $\mathrm{Hg}$, and $\mathrm{Sb}$ compared to fish oil and poultry fat. There was no difference between fat sources in the concentrations of the other detected TMs (Table 13). In Fig. 5, the number of times that each type of ingredient exceeded the MTL for the elements found in concentrations above this limit in commercial pet foods is illustrated. The results of the toxic metal concentrations in the analyzed mineral supplements are shown in Table 14. The sample of dicalcium phosphate analyzed was the one that presented the largest number of elements above the detection limit, so that only Se and As were in concentrations below the detection limit.

\section{Discussion}

Of all the toxic metals analyzed, it is noteworthy that selenium and iron are considered essential, as they have known biological functions important for the maintenance of vital functions, therefore they must be present in the food so that only the excess is considered harmful. The main findings of this study regarding contamination by toxic metals in commercial pet foods were the high concentrations of $\mathrm{Al}, \mathrm{Pb}, \mathrm{Hg}, \mathrm{U}$, and $\mathrm{V}$.

Aluminum. Concerning aluminum, in dog and cat foods, $31.9 \%$ and $10.71 \%$ had levels above the MTL, respectively. However, more than $75 \%$ of the analyzed foods exceeded the MTL less than 2.5 times. In a study conducted by da Costa ${ }^{45}$, which evaluated commercial foods for dogs and cats available in the Brazilian market, $\mathrm{Al}$ concentrations also determined by ICP-OES were above MTL in several pet foods. Fernandes ${ }^{38}$ also observed high $\mathrm{Al}$ concentrations (determined by instrumental neutron activation) in commercial dog foods, which ranged from 58 to $11900 \mathrm{mg} / \mathrm{kg}$ food, which corresponds to 59.5 times the MTL. In a study conducted by Paulelli ${ }^{46}, \mathrm{Al}$ concentrations in commercial dog and cat foods ranged from 12 to $519 \mathrm{mg} / \mathrm{kg}$ food, and dog foods had higher $\mathrm{Al}$ concentrations than cat foods, which is consistent with the present findings.

It is worth mentioning that there is little information in the literature regarding the $\mathrm{Al}$ toxicity in small animals, so the maximum intake that these animals can tolerate is not known. The MTL used in the present study as a parameter was extrapolated from the species most sensitive to this element, however, dogs and cats may be more tolerant to $\mathrm{Al}$ intake, consequently, a smaller proportion of the analyzed foods would be exceeding the aluminum tolerance for these species.

It is known that the $\mathrm{Al}$ absorption in the gastrointestinal tract is low (less than $1.0 \%$ in animals) and can be influenced by some factors such as solubility, $\mathrm{pH}$, and chemical presentation ${ }^{63}$. In addition, it has been shown that the presence of citric acid in the diet results in increased $\mathrm{Al}$ absorption in humans ${ }^{64}$, as well as increased $\mathrm{Al}$ retention in tissues of laboratory animals ${ }^{65-68}$. This inclusion of citric acid could increase the absorption of 

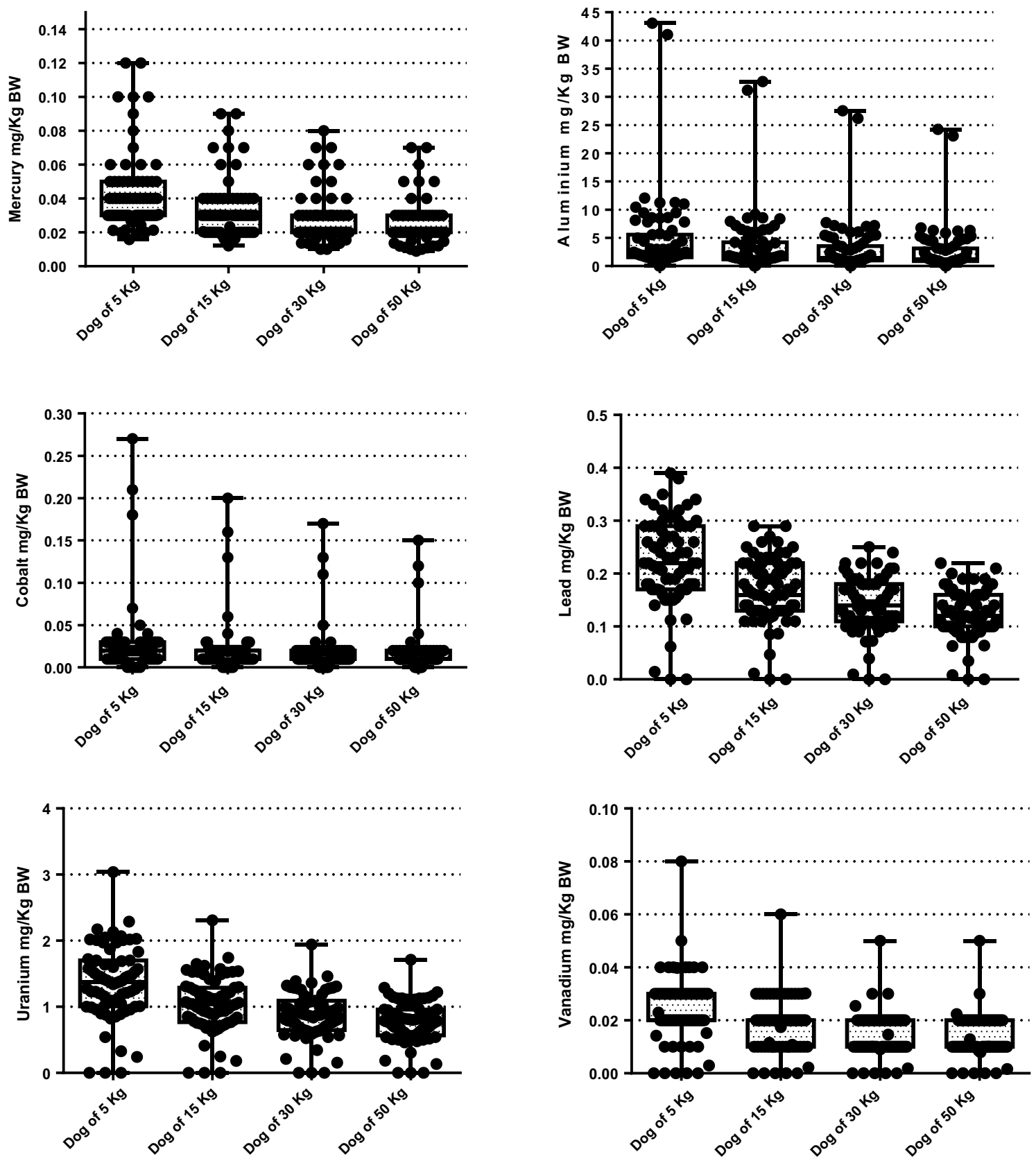

Figure 3. Estimated intake of the toxic metal that exceeded the maximum tolerated level (MTL) per kg of body weight (BW) of dogs of different sizes.

aluminum present in food by the gastrointestinal tract of dogs and cats and, especially in foods with high concentrations of this element, it would increase the risk of adverse effects.

In a study conducted by $\mathrm{Kat}^{69}$, four groups of Beagle dogs received sodium aluminum phosphate, in dosages of $0.0 \%, 0.3 \%, 1.0 \%$, and $3.0 \%$ for 6 months. Complete blood count, biochemical analyses, and urine tests were performed, in which no changes suggestive of toxicity were observed. The authors concluded that the "No Observed Adverse Effect Level" (NOAEL) was $70 \mathrm{mg} / \mathrm{kg} \mathrm{BW/day.} \mathrm{Pettersen}{ }^{70}$ evaluated the effects of consuming high Al doses (0-1143 mg/kg BW for males; 0-1251 mg/kg BW for females) in Beagles. Toxicity was limited to an acute and transient decrease in food consumption and a concomitant decrease in body weight, observed only in males. There were no changes in serum biochemistry, variables obtained from blood counts, and urinalysis. In the present study, it was calculated how much animals would consume of Al per $\mathrm{kg}$ of BW per day if they were fed these diets, and it was observed that none of the analyzed foods provided the amount of $70 \mathrm{mg} / \mathrm{kg} \mathrm{BW} / \mathrm{day}$. This suggests that the $\mathrm{Al}$ concentrations observed in this study do not imply risks of intoxication. Based on data from the present study, no food provided more than $45 \mathrm{mg} / \mathrm{kg}$ BW/day.

Regarding the $\mathrm{Al}$ concentrations in the analyzed ingredients, higher concentrations were found in the wheat bran, however, none of the samples of this ingredient exceeded the MTL for this element. The beef meal was the protein source with the highest $\mathrm{Al}$ concentrations, and $25 \%$ of the samples exceeded more than twice the MTL. 

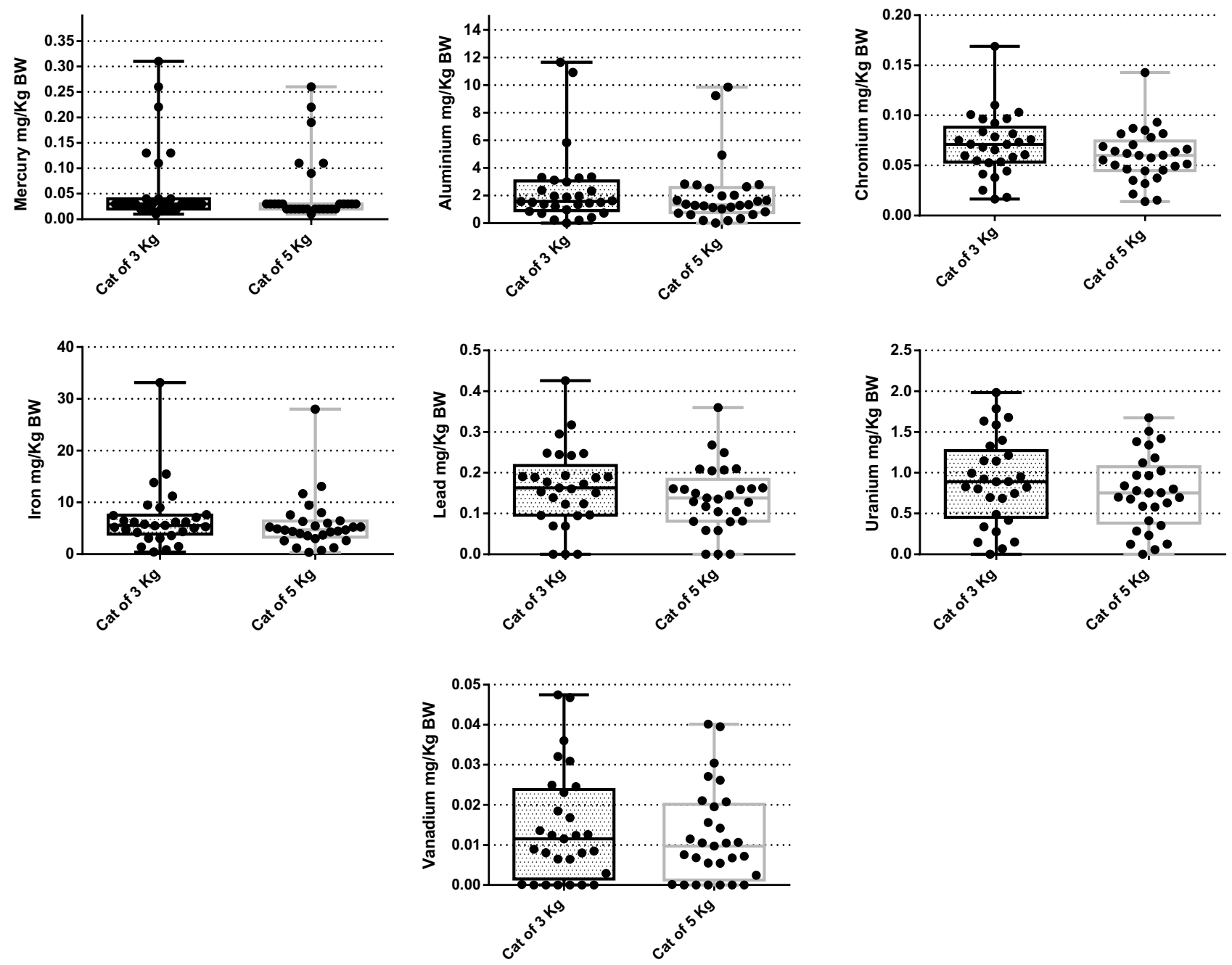

Figure 4. Estimated intake of toxic metals that exceeded the maximum tolerated level (MTL) and/or legal limit per kg of body weight (BW) of cats of two different sizes.

\begin{tabular}{|l|c|l|c|l|r|}
\hline Toxic metals & Dry foods & SEM & Wet foods & SEM & \multicolumn{1}{|l|}{$\boldsymbol{P}$} \\
\hline Aluminum $(\mathrm{Al})$ & $272.95^{\mathrm{a}}$ & 1.9077 & $108.14^{\mathrm{b}}$ & 2.0798 & $<0.0001$ \\
\hline Antimony $(\mathrm{Sb})$ & $2.3034^{\mathrm{a}}$ & 0.1752 & $1.7988^{\mathrm{a}}$ & 0.2682 & 0.1429 \\
\hline Barium $(\mathrm{Ba})$ & $26.1969^{\mathrm{a}}$ & 0.591 & $11.6018^{\mathrm{b}}$ & 0.6812 & $<0.0001$ \\
\hline Cadmium $(\mathrm{Cd})$ & $3.0493^{\mathrm{a}}$ & 0.2016 & $1.7146^{\mathrm{b}}$ & 0.2619 & 0.0008 \\
\hline Lead $(\mathrm{Pb})$ & $13.3327^{\mathrm{a}}$ & 0.4216 & $6.3767^{\mathrm{b}}$ & 0.505 & $<0.0001$ \\
\hline Cobalt $(\mathrm{Co})$ & $1.6788^{\mathrm{a}}$ & 0.1496 & $0.4394^{\mathrm{b}}$ & 0.1326 & $<0.0001$ \\
\hline Chromium $(\mathrm{Cr})$ & $4.8554^{\mathrm{a}}$ & 0.2544 & $3.4159^{\mathrm{b}}$ & 0.3696 & 0.0043 \\
\hline Tin $(\mathrm{Sn})$ & $9.9174^{\mathrm{a}}$ & 0.3636 & $9.4197^{\mathrm{a}}$ & 0.6138 & 0.4927 \\
\hline Iron $(\mathrm{Fe})$ & $323.04^{\mathrm{b}}$ & 2.0754 & $435.19^{\mathrm{a}}$ & 4.1723 & $<0.0001$ \\
\hline Mercury $(\mathrm{Hg})$ & $3.2469^{\mathrm{a}}$ & 0.2081 & $1.3552^{\mathrm{b}}$ & 0.2328 & $<0.0001$ \\
\hline Nickel $(\mathrm{Ni})$ & $1.758^{\mathrm{a}}$ & 0.1531 & $0.8002^{\mathrm{b}}$ & 0.1789 & 0.0014 \\
\hline Uranium $(\mathrm{U})$ & $80.9642^{\mathrm{a}}$ & 1.039 & $34.1501^{\mathrm{b}}$ & 1.1688 & $<0.0001$ \\
\hline Vanadium $(\mathrm{V})$ & $1.423^{\mathrm{a}}$ & 0.1377 & $0.5407^{\mathrm{b}}$ & 0.1471 & 0.0011 \\
\hline
\end{tabular}

Table 6. Comparison between the detected toxic metals concentrations ( $\mathrm{mg} / \mathrm{kg}$ ) in dry and wet foods in $\mathrm{mg} /$ $\mathrm{kg}$ of dry matter. SEM standard error mean, $P$ probability of significance. ${ }^{\mathrm{a}, \mathrm{b}}$ Means followed by different letters in the lines differed $(\mathrm{P}<0.05)$. 


\begin{tabular}{|l|c|l|l|l|c|}
\hline Toxic metals & Wet dog foods & SEM & Wet cat foods & SEM & $P$ \\
\hline Aluminum $(\mathrm{Al})$ & $115.84^{\mathrm{a}}$ & 3.2452 & $102.08^{\mathrm{b}}$ & 2.7003 & 0.0033 \\
\hline Antimony $(\mathrm{Sb})$ & $1.7858^{\mathrm{a}}$ & 0.4029 & $1.8091^{\mathrm{a}}$ & 0.3595 & 0.9659 \\
\hline Barium $(\mathrm{Ba})$ & $13.718^{\mathrm{a}}$ & 1.1167 & $9.9391^{\mathrm{b}}$ & 0.8426 & 0.0116 \\
\hline Cadmium $(\mathrm{Cd})$ & $1.7299^{\mathrm{a}}$ & 0.3966 & $1.7026^{\mathrm{a}}$ & 0.3487 & 0.9591 \\
\hline Lead $(\mathrm{Pb})$ & $5.9801^{\mathrm{a}}$ & 0.7373 & $6.6883^{\mathrm{a}}$ & 0.6912 & 0.4936 \\
\hline Cobalt $(\mathrm{Co})$ & $0.3862^{\mathrm{a}}$ & 0.1874 & $0.4813^{\mathrm{a}}$ & 0.1854 & 0.7255 \\
\hline Chromium $(\mathrm{Cr})$ & $3.4801^{\mathrm{a}}$ & 0.5625 & $3.3654^{\mathrm{a}}$ & 0.4903 & 0.8789 \\
\hline Tin $(\mathrm{Sn})$ & $9.7042^{\mathrm{a}}$ & 0.9393 & $9.1961^{\mathrm{a}}$ & 0.8105 & 0.685 \\
\hline Iron $(\mathrm{Fe})$ & $460.81^{\mathrm{a}}$ & 6.4724 & $415.07^{\mathrm{b}}$ & 5.445 & $<0.0001$ \\
\hline Mercury $(\mathrm{Hg})$ & $1.3323^{\mathrm{a}}$ & 0.348 & $1.3732^{\mathrm{a}}$ & 0.3132 & 0.9314 \\
\hline Nickel $(\mathrm{Ni})$ & $0.6435^{\mathrm{a}}$ & 0.2419 & $0.9233^{\mathrm{a}}$ & 0.2568 & 0.4479 \\
\hline Uranium $(\mathrm{U})$ & $31.1574^{\mathrm{b}}$ & 1.683 & $36.5015^{\mathrm{a}}$ & 1.6147 & 0.0331 \\
\hline Vanadium $(\mathrm{V})$ & $0.5088^{\mathrm{a}}$ & 0.2151 & $0.5658^{\mathrm{a}}$ & 0.201 & 0.8493 \\
\hline
\end{tabular}

Table 7. Comparison of detected toxic metals concentrations $(\mathrm{mg} / \mathrm{kg})$ between wet foods for dogs and cats. $S E M$ standard error mean, $P$ probability of significance. ${ }^{\mathrm{a}, \mathrm{b}}$ Means followed by different letters in the lines differed $(\mathrm{P}<0.05)$.

\begin{tabular}{|l|c|l|c|l|r|}
\hline Toxic metals & Dry dog foods & SEM & Dry cat foods & SEM & \multicolumn{1}{l|}{} \\
\hline Aluminum $(\mathrm{Al})$ & $296.8200^{\mathrm{a}}$ & 2.2059 & $168.9400^{\mathrm{b}}$ & 3.4738 & $<0.0001$ \\
\hline Antimony $(\mathrm{Sb})$ & $2.1563^{\mathrm{a}}$ & 0.1880 & $2.9443^{\mathrm{a}}$ & 0.4586 & 0.0852 \\
\hline Barium $(\mathrm{Ba})$ & $29.5342^{\mathrm{a}}$ & 0.6958 & $11.6557^{\mathrm{b}}$ & 0.9124 & $<0.0001$ \\
\hline Cadmium $(\mathrm{Cd})$ & $3.1375^{\mathrm{a}}$ & 0.2268 & $2.6646^{\mathrm{a}}$ & 0.4363 & 0.3643 \\
\hline Lead $(\mathrm{Pb})$ & $13.7379^{\mathrm{a}}$ & 0.4746 & $11.5672^{\mathrm{b}}$ & 0.9090 & 0.0488 \\
\hline Cobalt $(\mathrm{Co})$ & $1.8725^{\mathrm{a}}$ & 0.1752 & $0.8350^{\mathrm{b}}$ & 0.2442 & 0.0104 \\
\hline Chromium $(\mathrm{Cr})$ & $4.9510^{\mathrm{a}}$ & 0.2849 & $4.4387^{\mathrm{a}}$ & 0.5631 & 0.4354 \\
\hline Tin $(\mathrm{Sn})$ & $9.9140^{\mathrm{a}}$ & 0.4031 & $9.9319^{\mathrm{a}}$ & 0.8423 & 0.9847 \\
\hline Iron $(\mathrm{Fe})$ & $316.61^{\mathrm{b}}$ & 2.2782 & $351.0200^{\mathrm{a}}$ & 5.0073 & $<0.0001$ \\
\hline Mercury $(\mathrm{Hg})$ & $2.7167^{\mathrm{b}}$ & 0.2110 & $5.5569^{\mathrm{a}}$ & 0.6300 & $<0.0001$ \\
\hline Nickel $(\mathrm{Ni})$ & $1.8538^{\mathrm{a}}$ & 0.1743 & $1.3406^{\mathrm{a}}$ & 0.3094 & 0.1975 \\
\hline Uranium $(\mathrm{U})$ & $85.0520^{\mathrm{a}}$ & 1.1808 & $63.1533^{\mathrm{b}}$ & 2.1239 & $<0.0001$ \\
\hline Vanadium $(\mathrm{V})$ & $1.5062^{\mathrm{a}}$ & 0.1571 & $1.0605^{\mathrm{a}}$ & 0.2752 & 0.2137 \\
\hline
\end{tabular}

Table 8. Comparison of detected toxic metals concentrations $(\mathrm{mg} / \mathrm{kg})$ between dry foods for dogs and cats. $S E M$ standard error mean, $P$ probability of significance. ${ }^{\mathrm{a}, \mathrm{b}}$ Means followed by different letters in the lines differed $(\mathrm{P}<0.05)$.

Mercury. As for Hg concentrations, values much higher than the MTL were observed in all foods analyzed, both for dogs and cats. Other studies have evaluated $\mathrm{Hg}$ levels in commercial pet foods ${ }^{38,42-44,64}$, but none of them observed concentrations as high as in the present study. In contrast, in another study conducted by our research group, Pedrinelli ${ }^{57}$ found high $\mathrm{Hg}$ levels in homemade foods for dogs and cats, in which $70.7 \%$ and $76.0 \%$ of dog and cat foods exceeded MTL, respectively. In a study conducted by Luippold ${ }^{42}$, the authors evaluated the presence of mercury in 101 commercial foods (dry and wet foods) for dogs and cats, all of which contained fish as the main ingredient. The values found ranged from 0.001 to $0.604 \mathrm{mg} / \mathrm{kg}$ with an average concentration of $0.043 \mathrm{mg} /$ $\mathrm{kg}$, so some foods exceeded the MTL $(0.27 \mathrm{mg} / \mathrm{kg})$, but less than three times at most.

The Hg MTL recommended by FDA $^{59}$ was established based on the study by Charbonneau ${ }^{71}$ with cats, in which different oral doses of methylmercury, the most toxic form of $\mathrm{Hg}$, were tested and it was concluded that $0.02 \mathrm{mg} \mathrm{Hg} / \mathrm{kg} \mathrm{BW} /$ day did not cause adverse effects after 2 years. Thus, the FDA ${ }^{59}$ estimated that for a dog or cat to consume this daily amount, the food must have a $\mathrm{Hg}$ content of $0.27 \mathrm{mg} / \mathrm{kg}$ dry matter, which was established as the MTL for Hg. Most foods in the present study, both for dogs and cats, provided amounts of mercury above $0.02 \mathrm{mg} / \mathrm{kg} \mathrm{BW} /$ day. Among the adverse effects of high $\mathrm{Hg}$ intake, Charbonneau ${ }^{71}$ observed ataxia, loss of balance, and motor incoordination in the group of cats that consumed $0.176 \mathrm{mg}$ of Hg/kg BW/day after 14 weeks, and these same signs were observed after 40 weeks in the group that consumed $0.074 \mathrm{mg}$ of $\mathrm{Hg} / \mathrm{kg} \mathrm{BW} / \mathrm{day}$. Histopathological findings demonstrated neurological injuries.

It should be noted that the Hg MTL was determined based on the methylmercury consumption, the most toxic form of $\mathrm{Hg}$ found mainly in aquatic organisms. In the present study, the methodology employed did not allow quantifying the different $\mathrm{Hg}$ forms present in the samples, only the total $\mathrm{Hg}$ concentrations. It is assumed, however, that methylmercury is not the predominant form in the analyzed foods, since this organometallic compound 


\begin{tabular}{|l|l|l|l|l|c|l|c|}
\hline Toxic metals & Standard & SEM & Premium & SEM & Super premium & SEM & $P$ \\
\hline Aluminum $(\mathrm{Al})$ & $282.79^{\mathrm{b}}$ & 3.9637 & $276.62^{\mathrm{b}}$ & 3.468 & $332.67^{\mathrm{a}}$ & 4.0784 & $<0.0001$ \\
\hline Antimony $(\mathrm{Sb})$ & $2.0298^{\mathrm{a}}$ & 0.3358 & $2.3084^{\mathrm{a}}$ & 0.3168 & $2.0952^{\mathrm{a}}$ & 0.3237 & 0.8135 \\
\hline Barium $(\mathrm{Ba})$ & $45.7217^{\mathrm{a}}$ & 1.5938 & $23.0179^{\mathrm{b}}$ & 1.0004 & $22.4592^{\mathrm{b}}$ & 1.0597 & $<0.0001$ \\
\hline Boron $(\mathrm{B})$ & $0.000000153^{\mathrm{a}}$ & 0.000092 & $0.000000153^{\mathrm{a}}$ & 0.000082 & $0.000000153^{\mathrm{a}}$ & 0.000087 & 1 \\
\hline Cadmium $(\mathrm{Cd})$ & $3.5462^{\mathrm{a}}$ & 0.4567 & $3.1519^{\mathrm{a}}$ & 0.3702 & $2.9306^{\mathrm{a}}$ & 0.3828 & 0.5783 \\
\hline Lead $(\mathrm{Pb})$ & $14.8503^{\mathrm{a}}$ & 0.9083 & $13.5389^{\mathrm{a}}$ & 0.7672 & $12.9657^{\mathrm{a}}$ & 0.8052 & 0.2868 \\
\hline Cobalt $(\mathrm{Co})$ & $2.1111^{\mathrm{a}}$ & 0.3425 & $1.7649^{\mathrm{a}}$ & 0.277 & $1.7816^{\mathrm{a}}$ & 0.2985 & 0.6803 \\
\hline Chromium $(\mathrm{Cr})$ & $5.2126^{\mathrm{a}}$ & 0.5381 & $4.901^{\mathrm{a}}$ & 0.4616 & $4.7731^{\mathrm{a}}$ & 0.4885 & 0.8242 \\
\hline Tin $(\mathrm{Sn})$ & $9.738^{\mathrm{a}}$ & 0.7355 & $9.676^{\mathrm{a}}$ & 0.6486 & $10.3461^{\mathrm{a}}$ & 0.7192 & 0.7553 \\
\hline Iron $(\mathrm{Fe})$ & $337.6^{\mathrm{a}}$ & 4.3308 & $296.17^{\mathrm{c}}$ & 3.5884 & $321.24^{\mathrm{b}}$ & 4.0077 & $<0.0001$ \\
\hline Mercury $(\mathrm{Hg})$ & $2.4559^{\mathrm{a}}$ & 0.3694 & $2.9791^{\mathrm{a}}$ & 0.3599 & $2.6497^{\mathrm{a}}$ & 0.364 & 0.5902 \\
\hline Nickel $(\mathrm{Ni})$ & $2.0304^{\mathrm{a}}$ & 0.3359 & $1.8084^{\mathrm{a}}$ & 0.2804 & $1.7472^{\mathrm{a}}$ & 0.2956 & 0.799 \\
\hline Uranium (U) & $97.1009^{\mathrm{a}}$ & 2.3226 & $83.8141^{\mathrm{b}}$ & 1.909 & $75.6316^{\mathrm{c}}$ & 1.9446 & $<0.0001$ \\
\hline Vanadium (V) & $1.6406^{\mathrm{a}}$ & 0.3019 & $1.5607^{\mathrm{a}}$ & 0.2605 & $1.3226^{\mathrm{a}}$ & 0.2572 & 0.7039 \\
\hline
\end{tabular}

Table 9. Comparison of detected toxic metals concentrations $(\mathrm{mg} / \mathrm{kg})$ between different categories of dry dog foods. SEM standard error mean, $P$ probability of significance. ${ }^{\mathrm{a}, \mathrm{b}}$ Means followed by different letters in the lines differed $(\mathrm{P}<0.05)$

\begin{tabular}{|l|l|l|l|l|l|l|c|}
\hline Toxic metals & Standard & SEM & Premium & SEM & Super premium & SEM & $P$ \\
\hline Aluminum $(\mathrm{Al})$ & $180.54^{\mathrm{a}}$ & 6.7182 & $204.63^{\mathrm{a}}$ & 6.3973 & $123.97^{\mathrm{b}}$ & 4.9794 & $<0.0001$ \\
\hline Antimony $(\mathrm{Sb})$ & $2.9313^{\mathrm{a}}$ & 0.856 & $3.8247^{\mathrm{a}}$ & 0.8746 & $2.0742^{\mathrm{a}}$ & 0.6441 & 0.319 \\
\hline Barium $(\mathrm{Ba})$ & $9.2112^{\mathrm{a}}$ & 1.5175 & $13.6626^{\mathrm{a}}$ & 1.653 & $11.6045^{\mathrm{a}}$ & 1.5234 & 0.1997 \\
\hline Boron $(\mathrm{B})$ & $0.0000004158^{\mathrm{a}}$ & 0.000322 & $0.0000004158^{\mathrm{a}}$ & 0.000288 & $0.0000004158^{\mathrm{a}}$ & 0.000288 & 1 \\
\hline Cadmium $(\mathrm{Cd})$ & $2.006^{\mathrm{a}}$ & 0.7082 & $3.4741^{\mathrm{a}}$ & 0.8336 & $2.3821^{\mathrm{a}}$ & 0.6902 & 0.4003 \\
\hline Lead $(\mathrm{Pb})$ & $9.0741^{\mathrm{a}}$ & 1.5062 & $15.1531^{\mathrm{a}}$ & 1.7409 & $9.9758^{\mathrm{a}}$ & 1.4125 & 0.0412 \\
\hline Cobalt $(\mathrm{Co})$ & $0.4962^{\mathrm{a}}$ & 0.3522 & $1.2259^{\mathrm{a}}$ & 0.4952 & $0.7151^{\mathrm{a}}$ & 0.3782 & 0.5 \\
\hline Chromium $(\mathrm{Cr})$ & $3.6575^{\mathrm{a}}$ & 0.9562 & $5.5653^{\mathrm{a}}$ & 1.055 & $3.9369^{\mathrm{a}}$ & 0.8873 & 0.3614 \\
\hline Tin $(\mathrm{Sn})$ & $8.5373^{\mathrm{a}}$ & 1.4609 & $10.8585^{\mathrm{a}}$ & 1.4737 & $10.1211^{\mathrm{a}}$ & 1.4228 & 0.5585 \\
\hline Iron $(\mathrm{Fe})$ & $274.59^{\mathrm{c}}$ & 8.2854 & $354.18^{\mathrm{b}}$ & 8.4164 & $409.02^{\mathrm{a}}$ & 9.0446 & $<0.0001$ \\
\hline Mercury $(\mathrm{Hg})$ & $6.8257^{\mathrm{ab}}$ & 1.3063 & $7.1737^{\mathrm{a}}$ & 1.1978 & $2.9249^{\mathrm{b}}$ & 0.7648 & 0.0359 \\
\hline Nickel $(\mathrm{Ni})$ & $0.9347^{\mathrm{a}}$ & 0.4834 & $2.0178^{\mathrm{a}}$ & 0.6353 & $0.988^{\mathrm{a}}$ & 0.4445 & 0.318 \\
\hline Uranium $(\mathrm{U})$ & $57.7126^{\mathrm{b}}$ & 3.7984 & $74.2822^{\mathrm{a}}$ & 3.8544 & $56.3769^{\mathrm{b}}$ & 3.3579 & 0.0084 \\
\hline Vanadium $(\mathrm{V})$ & $0.7046^{\mathrm{a}}$ & 0.4197 & $1.5588^{\mathrm{a}}$ & 0.5584 & $0.8469^{\mathrm{a}}$ & 0.4116 & 0.4369 \\
\hline
\end{tabular}

Table 10. Comparison of detected toxic metals concentrations $(\mathrm{mg} / \mathrm{kg})$ between different categories of dry cat foods. SEM standard error mean, $P$ probability of significance. ${ }^{\mathrm{a}, \mathrm{b}}$ Means followed by different letters in the lines differed $(\mathrm{P}<0.05)$.

\begin{tabular}{|l|c|l|l|l|l|l|c|}
\hline Toxic metals & Wheat bran & SEM & Whole corn & SEM & Broken rice & SEM & $P$ \\
\hline Aluminum $(\mathrm{Al})$ & $61.1269^{\mathrm{a}}$ & 3.1918 & $33.5225^{\mathrm{b}}$ & 1.8309 & $4.8543^{\mathrm{c}}$ & 0.8995 & $<0.0001$ \\
\hline Barium $(\mathrm{Ba})$ & $21.8277^{\mathrm{a}}$ & 1.9073 & $0.3219^{\mathrm{b}}$ & 0.1794 & $0.3189^{\mathrm{b}}$ & 0.2305 & $<0.0001$ \\
\hline Lead $(\mathrm{Pb})$ & $13.5606^{\mathrm{a}}$ & 1.5034 & $5.8264^{\mathrm{b}}$ & 0.7633 & $3.5085^{\mathrm{b}}$ & 0.7647 & $<0.0001$ \\
\hline Cobalt $(\mathrm{Co})$ & $0.6809^{\mathrm{a}}$ & 0.3369 & $4.158 \mathrm{E}-07^{\mathrm{a}}$ & 0.000204 & $4.158 \mathrm{E}-07^{\mathrm{a}}$ & 0.000263 & 0.9993 \\
\hline Chromium $(\mathrm{Cr})$ & $2.5956^{\mathrm{a}}$ & 0.6577 & $0.4819^{\mathrm{b}}$ & 0.2314 & - & - & 0.0084 \\
\hline Tin $(\mathrm{Sn})$ & $7.2633^{\mathrm{a}}$ & 1.1002 & $3.4455^{\mathrm{b}}$ & 0.587 & $1.9679^{\mathrm{b}}$ & 0.5727 & 0.001 \\
\hline Iron $(\mathrm{Fe})$ & $156.06^{\mathrm{a}}$ & 5.1 & $40.9944^{\mathrm{b}}$ & 2.0247 & $4.2234^{\mathrm{c}}$ & 0.839 & $<0.0001$ \\
\hline Mercury $(\mathrm{Hg})$ & $2.00^{\mathrm{a}}$ & 0.5774 & - & - & $3.2166^{\mathrm{a}}$ & 0.8021 & 0.2443 \\
\hline Nickel $(\mathrm{Ni})$ & $1.7282^{\mathrm{b}}$ & 0.5367 & $5.3118^{\mathrm{a}}$ & 0.7288 & $0.1796^{\mathrm{b}}$ & 0.173 & 0.0007 \\
\hline Uranium $(\mathrm{U})$ & $116.38^{\mathrm{a}}$ & 4.4042 & $35.6404^{\mathrm{b}}$ & 1.8879 & $19.5955^{\mathrm{c}}$ & 1.8072 & $<0.0001$ \\
\hline Vanadium $(\mathrm{V})$ & $1.6922^{\mathrm{a}}$ & 0.5311 & $0.2646^{\mathrm{b}}$ & 0.1627 & - & - & 0.0177 \\
\hline
\end{tabular}

Table 11. Detected toxic metals concentrations $(\mathrm{mg} / \mathrm{kg})$ in the evaluated carbohydrate sources. SEM standard error mean, $P$ probability of significance. ${ }^{\mathrm{a}, \mathrm{b}}$ Means followed by different letters in the lines differed $(\mathrm{P}<0.05)$. 


\begin{tabular}{|c|c|c|c|c|c|c|c|c|c|c|c|c|c|c|c|}
\hline $\begin{array}{l}\text { Toxic } \\
\text { metals }\end{array}$ & $\begin{array}{l}\text { Beef } \\
\text { meal }\end{array}$ & SEM & CGM 21 & SEM & CGM 60 & SEM & $\begin{array}{l}\text { Fish } \\
\text { meal }\end{array}$ & SEM & $\begin{array}{l}\text { Feather } \\
\text { meal }\end{array}$ & SEM & $\begin{array}{l}\text { Soybean } \\
\text { meal }\end{array}$ & SEM & $\begin{array}{l}\text { Chicken } \\
\text { by-products } \\
\text { meal }\end{array}$ & SEM & $P$ \\
\hline $\mathrm{Al}$ & $221.85^{\mathrm{a}}$ & 5.2660 & $62.0251^{\mathrm{d}}$ & 3.2152 & $95.4710^{c}$ & 3.9890 & $73.6629^{d}$ & 3.5039 & $62.8442^{\mathrm{d}}$ & 3.2364 & $148.43^{\mathrm{b}}$ & 4.9737 & $49.1379^{e}$ & 1.7525 & $<0.0001$ \\
\hline As & $0.0000^{\mathrm{a}}$ & $<0.0001$ & $0.2392^{\mathrm{a}}$ & \begin{tabular}{|l|}
0.1997 \\
\end{tabular} & $0.0000^{\mathrm{a}}$ & 0.0002 & $0.000^{\mathrm{a}}$ & 0.0002 & $0.000^{\mathrm{a}}$ & \begin{tabular}{|l|}
0.0002 \\
\end{tabular} & $0.000^{\mathrm{a}}$ & 0.0002 & $0.000^{\mathrm{a}}$ & \begin{tabular}{|l|}
0.0001 \\
\end{tabular} & 1.000 \\
\hline B & - & - & - & - & - & - & - & - & - & - & 20.213 & 1.8354 & - & - & - \\
\hline $\mathrm{Ba}$ & $136.59^{\mathrm{a}}$ & 4.1321 & $0.2957^{\mathrm{d}}$ & 0.2220 & $0.3342^{\mathrm{d}}$ & 0.2360 & $3.7413^{c}$ & 0.7897 & $4.4303^{c}$ & 0.8593 & $9.9167^{\mathrm{b}}$ & 1.2856 & $11.8609^{\mathrm{b}}$ & 0.8610 & $<0.0001$ \\
\hline $\mathrm{Cd}$ & $6.0219^{\mathrm{a}}$ & 0.8676 & - & - & - & - & $3.9481^{\mathrm{ab}}$ & 0.8112 & - & - & - & - & $2.6884^{\mathrm{b}}$ & \begin{tabular}{|l|}
0.4099 \\
\end{tabular} & \begin{tabular}{|l|}
0.0027 \\
\end{tabular} \\
\hline Co & $3.4913^{\mathrm{a}}$ & 0.6606 & $0.0807^{\mathrm{ab}}$ & 0.1159 & $0.0063^{\mathrm{ab}}$ & 0.0325 & $1.8144^{\mathrm{ab}}$ & 0.5499 & $0.3442^{\mathrm{b}}$ & 0.2395 & $1.1074^{\mathrm{ab}}$ & 0.4296 & $1.1094^{\mathrm{b}}$ & 0.2633 & \begin{tabular}{|l|}
0.0006 \\
\end{tabular} \\
\hline $\mathrm{Cr}$ & $10.0963^{\mathrm{a}}$ & 1.1234 & $0.7348^{\mathrm{d}}$ & 0.3499 & $1.0127^{\mathrm{d}}$ & 0.4108 & $5.8104^{\mathrm{ab}}$ & 0.9841 & $1.7835^{\mathrm{cd}}$ & 0.5452 & $2.4648^{\mathrm{bcd}}$ & 0.6409 & $3.7841^{\mathrm{bc}}$ & 0.4863 & $<0.0001$ \\
\hline $\mathrm{Fe}$ & $257.08^{\mathrm{b}}$ & 5.6688 & $115.86^{\mathrm{e}}$ & 4.3943 & $136.41^{\mathrm{d}}$ & 4.7682 & $213.07^{\mathrm{c}}$ & 5.9592 & $522.37^{\mathrm{a}}$ & \begin{tabular}{|l|}
9.3307 \\
\end{tabular} & $191.20^{c}$ & 5.6451 & $199.02^{c}$ & 3.5269 & $<0.0001$ \\
\hline $\mathrm{Hg}$ & $6.195^{\mathrm{a}}$ & 0.880 & $1.632^{\mathrm{b}}$ & 5.222 & - & - & - & - & $0.284^{\mathrm{b}}$ & 0.217 & $0.350^{\mathrm{b}}$ & 0.242 & $5.045^{\mathrm{a}}$ & 0.5615 & $<0.0001$ \\
\hline $\mathrm{Ni}$ & $4.1005^{\mathrm{a}}$ & 0.7159 & $0.2195^{\mathrm{b}}$ & 0.1913 & $0.0553^{\mathrm{ab}}$ & 0.0960 & $2.3281^{\mathrm{ab}}$ & 0.6229 & $0.5534^{\mathrm{b}}$ & 0.3037 & $2.0148^{\mathrm{ab}}$ & 0.5795 & $1.4225^{\mathrm{b}}$ & 0.2982 & \begin{tabular}{|l|}
0.0001 \\
\end{tabular} \\
\hline $\mathrm{Pb}$ & $44.2657^{\mathrm{a}}$ & 2.3523 & 3.5215f. & 0.7661 & $5.1178^{\mathrm{ef}}$ & 0.9236 & $26.4557^{\mathrm{b}}$ & 2.0998 & $9.6875^{\mathrm{de}}$ & 1.2707 & \begin{tabular}{|l}
$14.2407^{\mathrm{cd}}$ \\
\end{tabular} & 1.5406 & $19.0577^{\mathrm{c}}$ & 1.0914 & $<0.0001$ \\
\hline $\mathrm{Sb}$ & $0.3732^{\mathrm{b}}$ & 0.216 & $10.76^{\mathrm{a}}$ & 1.6406 & - & - & - & - & $8.72^{\mathrm{a}}$ & 2.0884 & - & - & $0.1691^{\mathrm{b}}$ & \begin{tabular}{|l|}
0.1679 \\
\end{tabular} & $<0.0001$ \\
\hline Sn & $22.8075^{\mathrm{a}}$ & 1.6885 & $6.4901^{\mathrm{d}}$ & 1.0400 & $6.5571^{\mathrm{d}}$ & 1.0454 & $15.1641^{b}$ & 1.5898 & $8.7319^{\mathrm{cd}}$ & 1.2064 & $8.3889^{\mathrm{cd}}$ & 1.1824 & $12.7898^{\mathrm{bc}}$ & 0.8941 & $<0.0001$ \\
\hline $\mathrm{U}$ & $201.68^{\mathrm{a}}$ & 5.0209 & $36.3262^{\mathrm{e}}$ & 2.4606 & $31.9928^{\mathrm{e}}$ & 2.3091 & $126.17^{\mathrm{b}}$ & 4.5856 & $50.154^{\mathrm{d}}$ & 2.8912 & $110.28^{\mathrm{b}}$ & 4.2871 & $94.6199^{c}$ & 2.4318 & $<0.0001$ \\
\hline $\mathrm{V}$ & $5.1708^{\mathrm{a}}$ & 0.8040 & $0.4283^{c}$ & 0.2672 & $0.2473^{c}$ & 0.2030 & $3.5753^{\mathrm{ab}}$ & 0.7719 & $0.7391^{\mathrm{bc}}$ & 0.351 & $1.8167^{\mathrm{abc}}$ & 0.5503 & $2.1038^{\mathrm{bc}}$ & 0.3626 & $<0.0001$ \\
\hline
\end{tabular}

Table 12. Detected toxic metals concentrations ( $\mathrm{mg} / \mathrm{kg})$ in the evaluated protein sources. $A l$ aluminum, $A s$ arsenic, $B$ boron, $\mathrm{Ba}$ barium, $\mathrm{Cd}$ cadmium, $\mathrm{Co}$ cobalt, $\mathrm{Cr}$ chromium, $\mathrm{Cu}$ copper, $\mathrm{Fe}$ iron, $\mathrm{Hg}$ mercury, $\mathrm{Ni}$ nickel, $\mathrm{Pb}$ lead, $\mathrm{Sb}$ antimony, $S n$ tin, $U$ uranium, $V$ vanadium, $Z n$ zinc, $C G M 21$ corn gluten meal 21, CGM 60 corn gluten meal 60, SEM standard error mean, $P$ probability of significance. ${ }^{\mathrm{a}, \mathrm{b}}$ Means followed by different letters in the lines differed $(\mathrm{P}<0.05)$.

\begin{tabular}{|l|l|l|l|l|l|}
\hline Toxic metals & Pork fat & Fish oil & Poultry fat & SEM & P \\
\hline Mercury $(\mathrm{Hg})$ & $0.81^{\mathrm{a}}$ & $0.00^{\mathrm{b}}$ & $0.00^{\mathrm{b}}$ & 0.249 & 0.0546 \\
\hline Arsenic $(\mathrm{As})$ & $1.01^{\mathrm{a}}$ & $0.34^{\mathrm{b}}$ & $0.00^{\mathrm{b}}$ & 0.158 & 0.0013 \\
\hline Antimony $(\mathrm{Sb})$ & $0.99^{\mathrm{a}}$ & $0.12^{\mathrm{b}}$ & $0.00^{\mathrm{b}}$ & 0.185 & 0.0033 \\
\hline Aluminum $(\mathrm{Al})$ & 4.51 & 0.51 & 0.01 & 1.976 & 0.2433 \\
\hline Cadmium $(\mathrm{Cd})$ & 0.73 & 0.54 & 0.52 & 0.352 & 0.8978 \\
\hline Iron $(\mathrm{Fe})$ & 0.00 & 1.15 & 0.37 & 0.444 & 0.2045 \\
\hline Nickel $(\mathrm{Ni})$ & 0.15 & 0.00 & 0.28 & 0.177 & 0.5461 \\
\hline Tin $(\mathrm{Sn})$ & 7.12 & 10.38 & 6.85 & 1.752 & 0.3131 \\
\hline
\end{tabular}

Table 13. Detected toxic metals concentrations $(\mathrm{mg} / \mathrm{kg})$ in the evaluated fat sources. SEM standard error mean, $P$ probability of significance. ${ }^{\mathrm{a}, \mathrm{b}}$ Means followed by different letters in the lines differed $(\mathrm{P}<0.05)$ by tukey test.

is found in fish and other aquatic organisms, in which over $90 \%$ of the $\mathrm{Hg}$ is in the form of methylmercury $\mathrm{y}^{72,73}$. In most of the analyzed foods, fish by-products or other aquatic organisms were not present, according to what was stated on the labels. In addition, none of the samples of fish meal and fish oil analyzed in our study had $\mathrm{Hg}$ concentrations above the detection limit. This suggests that the chemical $\mathrm{Hg}$ form in the analyzed foods is not methylmercury, i.e., it may be a less toxic form, which in the concentrations found in this study, may not have adverse effects on the health of pets. However, this aspect needs to be further investigated.

In our study, dry foods had higher $\mathrm{Hg}$ concentrations than wet foods, results opposite to those observed by Luippold ${ }^{42}$ and Paulelli ${ }^{46}$. Concerning dry foods, those intended for cats had higher $\mathrm{Hg}$ concentrations than those found in dog food. This could be attributed to the greater inclusion of protein to meet the higher protein requirement of the feline species, since animal protein sources, more specifically beef meal and chicken by-products, were the ingredients with the highest $\mathrm{Hg}$ contamination and are widely used in dry pet food formulation.

As previously mentioned, no fish meal samples had $\mathrm{Hg}$ concentrations above the detection limit, although fish is considered the main $\mathrm{Hg}$ poisoning pathway in humans ${ }^{74,75}$. In the study conducted by $\mathrm{Kim}^{44}$, when determining toxic metals in commercial dry dog foods, the authors found higher Hg concentrations in food whose primary protein source was based on fish by-products, compared to those foods whose main protein source was by-products derived from red meat and poultry. A variety of factors can influence $\mathrm{Hg}$ contamination in fish, such as species, place of origin, whether it originates from pisciculture or the natural environment, feed, life span, and size ${ }^{73}$. It is known that fish meal can come from two sources, fishery by-products and fish caught exclusively for the production of this ingredient ${ }^{76}$. Therefore, all of these factors can influence $\mathrm{Hg}$ contamination in the fish meal used in pet food. Some studies have shown that fish from pisciculture has less $\mathrm{Hg}$ contamination than fish from natural environments ${ }^{77,78}$. 
www.nature.com/scientificreports/

Mercury

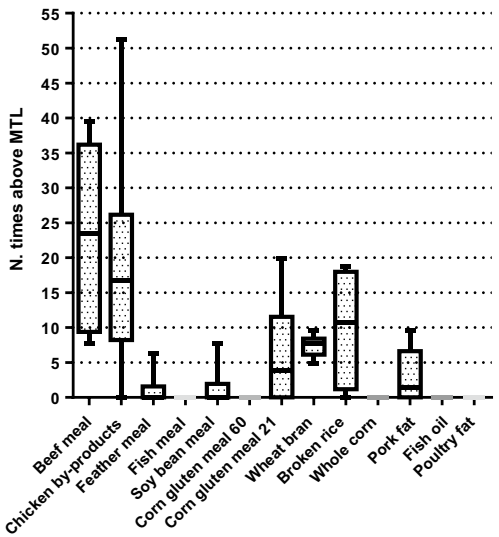

Iron

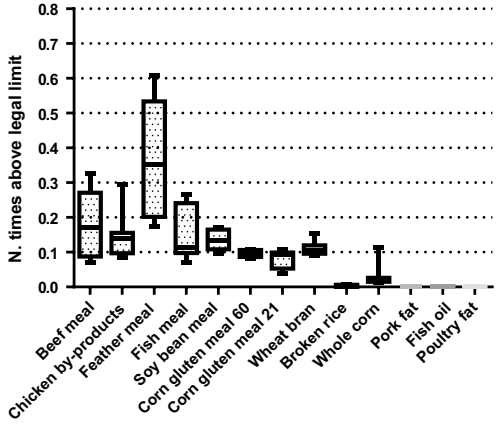

Aluminum

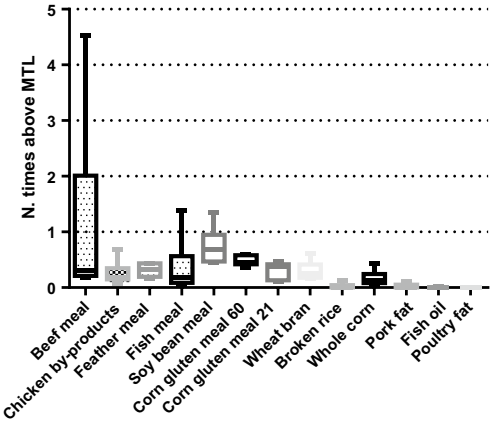

Lead

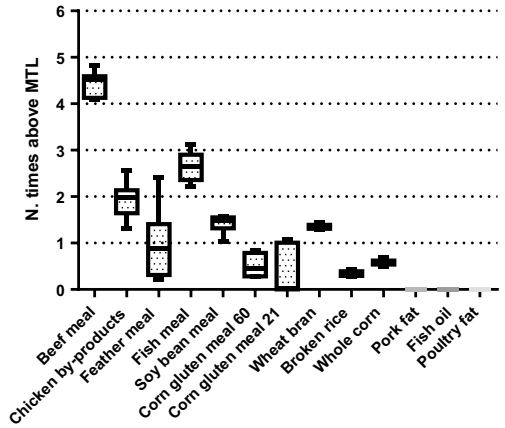

Vanadium

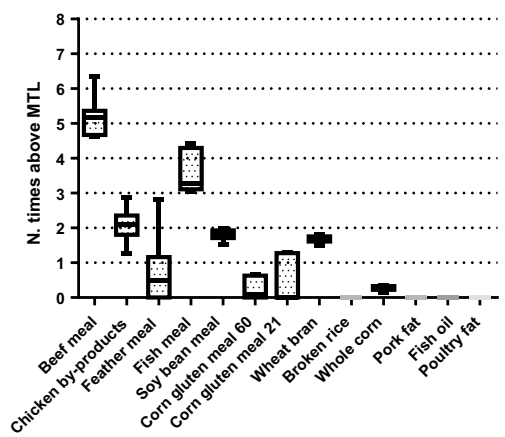

Cobalt

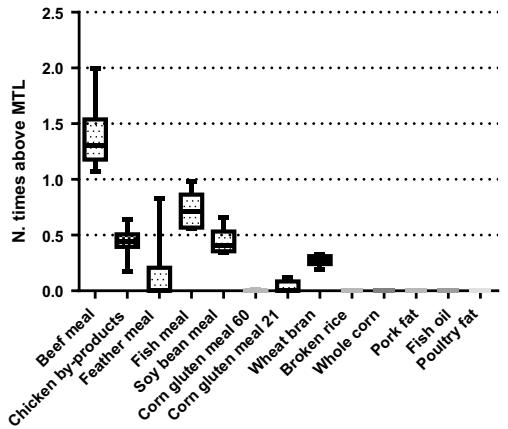

Uranium

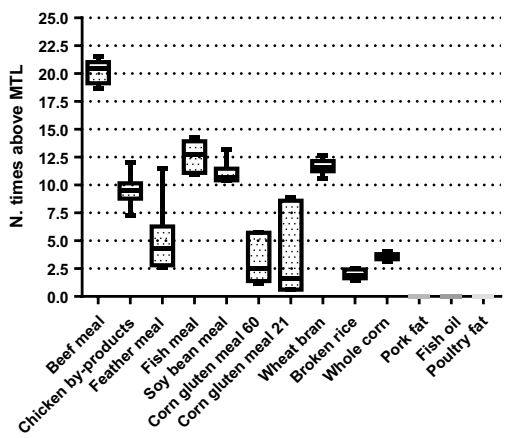

Figure 5. Number of times above maximum tolerated level (MTL) and/or legal limit for toxic metals in ingredients of animal and vegetable origin.

In Brazil, salmon (scientific name: Salmo safar) is widely used in fish meal employed by the pet food industry and, according to Ginsberg ${ }^{79}$, regarding the risk of $\mathrm{Hg}$ poisoning in humans, salmon is not worrisome. Furthermore, in the study conducted by Olmedo ${ }^{80}$, in which toxic metals were evaluated in several fish species, low $\mathrm{Hg}$ concentrations were found in salmon samples, of which the median and interval between 5 and 95 th percentiles were 0 (0-0.004). This could explain the Hg concentrations below the detection limit in the fish meal samples analyzed in the present study. In addition, fish meal may come from waste from the tilapia filleting industry ${ }^{81}$, the most produced fish species in Brazil ${ }^{82}$, and low $\mathrm{Hg}$ concentrations in this species have been reported. In the study by Kitahara ${ }^{74}$, where samples of 11 different species of freshwater fish were analyzed, tilapia was the one with the lowest concentrations, ranging from 0.01 to $0.02 \mathrm{mg} / \mathrm{kg}$. This could also justify the non-detection of mercury in the fish meal analyzed in our study.

In reference to the $\mathrm{Hg}$ contents in the analyzed carbohydrate sources, this toxic metal was not quantified above the detection limit in any whole corn sample, and wheat bran did not differ from broken rice. Among protein sources, in addition to fish meal, no $\mathrm{Hg}$ was present above the detection limit in any sample of corn gluten meal 60. Beef meal and chicken by-products meal showed higher concentrations, compared to other sources.

Other ingredients could be considered potential contaminants, such as broken rice since more than $50 \%$ of the samples exceeded the MTL more than ten times, as well as corn gluten meal 21, which had values up to 20 times higher than the MTL. These ingredients, in addition to having high $\mathrm{Hg}$ concentrations, can be included

Scientific Reports |

(2021) 11:21007 |

https://doi.org/10.1038/s41598-021-00467-4

nature portfolio

13 


\begin{tabular}{|l|l|l|l|l|l|l|}
\hline Toxic metals & $\begin{array}{l}\text { Sodium chloride } \\
\mathbf{1}\end{array}$ & $\begin{array}{l}\text { Sodium chloride } \\
\mathbf{2}\end{array}$ & $\begin{array}{l}\text { Potassium } \\
\text { chloride 1 }\end{array}$ & $\begin{array}{l}\text { Potassium } \\
\text { chloride 2 }\end{array}$ & $\begin{array}{l}\text { Calcium } \\
\text { carbonate }\end{array}$ & $\begin{array}{l}\text { Dicalcium } \\
\text { phosphate }\end{array}$ \\
\hline Aluminum $(\mathrm{Al})$ & 11.85 & $<0.05$ & $<0.05$ & $<0.05$ & 316.39 & 499.54 \\
\hline Antimony $(\mathrm{Sb})$ & $<0.05$ & $<0.05$ & $<0.05$ & $<0.05$ & $<0.05$ & 0.64 \\
\hline Arsenic $(\mathrm{As})$ & $<0.05$ & $<0.05$ & $<0.05$ & $<0.05$ & $<0.05$ & $<0.05$ \\
\hline Barium $(\mathrm{Ba})$ & 0.27 & 0.27 & 0.19 & 0.46 & 1.46 & 1.16 \\
\hline Beryllium $(\mathrm{Be})$ & $<0.05$ & $<0.05$ & $<0.05$ & $<0.05$ & $<0.05$ & 6.37 \\
\hline Boron $(\mathrm{B})$ & $<0.05$ & $<0.05$ & $<0.05$ & $<0.05$ & $<0.05$ & $<0.05$ \\
\hline Cadmium $(\mathrm{Cd})$ & $<0.05$ & $<0.05$ & $<0.05$ & $<0.05$ & 5.83 & 10.12 \\
\hline Lead $(\mathrm{Pb})$ & 3.85 & 2.62 & 0.72 & 3.49 & 66.29 & 92.51 \\
\hline Cobalt $(\mathrm{Co})$ & $<0.05$ & $<0.05$ & $<0.05$ & $<0.05$ & 4.44 & 3.05 \\
\hline Chromium $(\mathrm{Cr})$ & $<0.05$ & $<0.05$ & $<0.05$ & $<0.05$ & 13.41 & 24.21 \\
\hline Tin $(\mathrm{Sn})$ & 0.50 & 0.86 & 0.12 & 0.06 & 25.71 & 29.65 \\
\hline Iron $(\mathrm{Fe})$ & 6.55 & 2.89 & 7.55 & 2.20 & 140.62 & $10,792.48$ \\
\hline Mercury $(\mathrm{Hg})$ & $<0.05$ & $<0.05$ & $<0.05$ & $<0.05$ & 6.08 & 4.63 \\
\hline Nickel $(\mathrm{Ni})$ & $<0.05$ & $<0.05$ & $<0.05$ & $<0.05$ & 8.44 & 45.84 \\
\hline Selenium $(\mathrm{Se})$ & $<0.05$ & $<0.05$ & $<0.05$ & $<0.05$ & $<0.05$ & $<0.05$ \\
\hline Uranium $(\mathrm{U})$ & 13.95 & 12.60 & 10.31 & 15.81 & 281.24 & 673.24 \\
\hline Vanadium $(\mathrm{V})$ & 0.26 & 0.02 & $<0.05$ & 0.07 & 7.83 & 29.246 \\
\hline
\end{tabular}

Table 14. Toxic metals concentrations $(\mathrm{mg} / \mathrm{kg})$ of in the analyzed mineral supplements. SEM standard error mean, $P$ probability of significance. ${ }^{\mathrm{a}, \mathrm{b}}$ Means followed by different letters in the lines differed $(\mathrm{P}<0.05)$.

in high amounts in the formulation of dry foods for dogs and cats and are widely used by the pet food industry. Perhaps this justifies the high $\mathrm{Hg}$ concentrations found in the dry foods analyzed in this study. Some samples of swine fat had high $\mathrm{Hg}$ concentrations, with a maximum value almost ten times above MTL of $\mathrm{Hg}$, so the inclusion of this ingredient can also significantly influence $\mathrm{Hg}$ concentrations in commercial pet food.

Lead. Regarding Pb concentrations in the analyzed dog and cat foods, $80.55 \%$ and $32.14 \%$ exceeded the MTL for this element, respectively. Although a large portion of the foods, especially those intended for dogs, exceeded the MTL, only two dog foods and one cat food exceeded the MTL more than two times. Similar results were observed by Duran ${ }^{40}$ in pet foods marketed in Turkey. In contrast, in another study evaluating commercial pet foods sold in Brazil, lower $\mathrm{Pb}$ concentrations $\left(0.05-1.4 \mathrm{mg} / \mathrm{kg}\right.$ ) were observed ${ }^{61}$. Pedrinelli ${ }^{57}$ also observed $\mathrm{Pb}$ concentrations above the MTL in homemade foods for dogs and cats prepared with Brazilian ingredients.

Of the analyzed ingredients, wheat bran was the carbohydrate source with the highest Pb levels, while the beef meal was the protein source that presented the highest concentrations of this toxic metal. In addition, values more than two times above the Pb MTL were observed in samples of chicken by-products meal, feather meal, and fish meal, which can contribute to the contamination of the final product if these ingredients are used in high quantities. The higher $\mathrm{Pb}$ levels found in beef meal corroborate the results found in the study performed by $\mathrm{Kim}^{44}$, higher $\mathrm{Pb}$ concentrations were observed in dog foods, in which red meat was the main protein source based on the list of ingredients stated on the label, compared to foods composed mainly of chicken and fish proteins. In that study, the maximum $\mathrm{Pb}$ concentration was also found in red meat-based foods, which was 270 times higher than the average human daily intake in units per megacalories estimated by Thomas ${ }^{83}$. The medians of the results found in the chicken- and fish-based foods exceeded the average daily human intake by 6 and 8 times, respectively.

As for the mineral supplements analyzed, high $\mathrm{Pb}$ concentrations were observed in the samples of calcium carbonate and dicalcium phosphate, which exceeded the MTL by 6.63 and 9.25 times, respectively. Although these ingredients are used in small quantities, compared to carbohydrate and protein sources, they could also contribute to the contamination of the final product. Environmental contamination by $\mathrm{Pb}$ is mainly due to the burning of fossil fuels (coal, natural gas, and oil) and the mining industry. In the past, tetraethyl lead was added to increase the gasoline octane rating, and the burning of this fuel was considered the main source of environmental contamination by $\mathrm{Pb}$. Although this practice was banned in 1989, a large part of the $\mathrm{Pb}$ present in Brazilian soils is still attributed to tetraethyl lead ${ }^{81}$, which may justify the results observed in the present study.

With regard to the adverse effects of $\mathrm{Pb}$ excess, it is known that its toxicity may involve gastrointestinal signs $^{50,51}$, neurological disorders ${ }^{50,52}$, damage to the hematopoietic system ${ }^{53,54}$, and kidney injuries ${ }^{52}$. Pb MTL was established based on a study in which there were no adverse effects related to the consumption of a diet with $10 \mathrm{mg} / \mathrm{kg}$ of $\mathrm{Pb}$ in dogs for a period of 2 years $^{84}$. It is not known whether the $\mathrm{Pb}$ levels in the foods evaluated in the present study that exceeded the MTL can cause adverse effects, noting that three foods exceeded this limit by more than two times. In the study conducted by Steiss ${ }^{85}$, neuropathy or histological changes in the central nervous system were not observed in dogs that consumed an oral dose of $5 \mathrm{mg}$ of Pb/kg BW/day for 40 weeks. Two dogs, however, showed evidence of non-regenerative anemia after 24 and 26 weeks of consumption. In our study, through the simulation of $\mathrm{Pb}$ consumption per $\mathrm{kg}$ of $\mathrm{BW}$, the highest values observed were approximately $0.4 \mathrm{mg} / \mathrm{kg} \mathrm{BW}$ for dogs and $0.5 \mathrm{mg} / \mathrm{kg} \mathrm{BW}$ for cats, much lower than the dose studied by Steiss ${ }^{85}$, suggesting a 
safety margin in the analyzed foods. In addition, according to Wismer ${ }^{86}$, the chronic accumulative toxic dose of $\mathrm{Pb}$ for dogs is $1.8-2.6 \mathrm{mg} / \mathrm{kg} \mathrm{BW/day,} \mathrm{much} \mathrm{higher} \mathrm{than} \mathrm{the} \mathrm{amount} \mathrm{estimated} \mathrm{in} \mathrm{our} \mathrm{study.}$

Uranium. Of the analyzed dog and cat foods, $85.71 \%$ and $95.85 \%$ exceeded the MTL for uranium, respectively. In addition to this large portion having exceeded the MTL, the observed values exceeded this limit by up to 14 times. High $U$ concentrations were also found in homemade foods for dogs and cats in the study performed by Pedrinelli ${ }^{57}$, in which $92 \%$ of the recipes for dogs and $100 \%$ of the recipes for cats exceeded the MTL, with values up to 16 times higher.

As for the analyzed ingredients, wheat bran was the carbohydrate source that showed the highest $U$ concentrations and, among the protein sources, higher $U$ concentrations were found in the beef meal. Regarding the analyzed mineral supplements, high $U$ concentrations were observed in the samples of calcium carbonate $(281.24 \mathrm{mg} / \mathrm{kg})$ and dicalcium phosphate $(673.24 \mathrm{mg} / \mathrm{kg})$, which corresponds to 28.12 and 67.32 times the MTL of that element, respectively.

In addition to the high concentrations observed in these ingredients, it is worth mentioning that most of the ingredients of animal and vegetable origin had concentrations much higher than U MTL, such as beef meal, of which all samples evaluated exceeded more than 17.5 times the MTL. All samples of fish meal, soybean meal, and wheat bran exceeded the MTL by more than ten times. In the case of chicken by-products meal, all samples exceeded more than 7.5 times the MTL. Due to the widespread use of these ingredients in the manufacture of commercial pet foods, these results may justify the high $U$ concentrations observed in the commercial pet foods analyzed in this study.

Brazil has the fifth largest $U$ reserve in the world, totaling 309,000 tonnes of this element, representing more than $5 \%$ of the total in the world ${ }^{87}$. This could justify the high $U$ concentrations observed in the present study, since the exploration of uranium mines may result in contamination of water and soil and, consequently, of the ingredients used by the pet food industry. Furthermore, according to Prado ${ }^{88}$, contamination with uranium in foods occurs mainly as a consequence of its presence in phosphate rocks, from which fertilizers and mineral supplements used in animal feed, such as phosphate, are extracted. Of all the samples of ingredients analyzed, the sample of dicalcium phosphate showed the highest $U$ concentration $(623 \mathrm{mg} / \mathrm{kg})$. The $U$ contamination in plant-based products could be attributed to the use of phosphates as soil fertilizers, whereas the contamination of animal by-products could occur due to the consumption of phosphate by animals as a mineral supplement, as well as the consumption of vegetables contaminated by the continuous use of phosphate as a fertilizer.

The $\mathrm{U}$ concentrations in the analyzed foods are worrying, as this metal is considered one of the heaviest toxic elements present in the environment and is a precursor to natural radionuclides, therefore it emits alpha and gamma radiation ${ }^{89}$. In the study conducted by these latter authors, the effects of $U$ consumption by growing dogs on bone $U$ deposition were evaluated, as well as on clinical and histopathological changes. In that study, one Beagle consumed a diet containing $20 \mathrm{mg} / \mathrm{kg}$ of uranium and three other dogs of the same breed consumed a diet with $100 \mathrm{mg} / \mathrm{kg}$ of uranium for 279 days. On the histopathological examination, glomerular degeneration was observed in the three animals that consumed the food with the highest $U$ content. However, no changes were observed in the animal that consumed the diet with $20 \mathrm{mg} / \mathrm{kg}$ of uranium. In our study, two cat foods and $12 \mathrm{dog}$ foods had $\mathrm{U}$ concentrations above $100 \mathrm{mg} / \mathrm{kg}$, which could imply risks of glomerular injury. However, it is worth noting that in the study by Arruda-Neto ${ }^{89}$, growing dogs were evaluated, which are perhaps more susceptible to the harmful effects of uranium, in addition to consuming a larger amount of food (consequently more uranium) per kg of metabolic weight, due to the greater energy and nutritional requirements in this stage of life.

It is noteworthy that for the determination of MTL, due to the lack of information in the literature regarding the $\mathrm{U}$ toxicity to dogs and cats, the $\mathrm{FDA}^{59}$ used the MTL of the most sensitive mammal to this toxic metal, which in this case are rodents, and reduced this value by ten times, as suggested when extrapolating between species. According to Vicente-Vicente ${ }^{90}$, when comparing dogs and rodents with respect to sensitivity to U inhalation, less sensitivity was observed in dogs. This suggests that perhaps dogs are also less sensitive to $U$ intake than rodents, in this case, there would be no need to reduce the U MTL by ten times when extrapolating rodents to dogs. Therefore, a smaller portion of the analyzed foods would be above this limit. Concerning cats, there is no study to date that has investigated the effects of $U$ consumption or inhalation.

Vanadium. As for V, 75\% and $28.57 \%$ of dog and cat foods exceeded the MTL for this element, respectively. However, the majority exceeded less than two times that limit. Due to the lack of information regarding the $\mathrm{V}$ toxicity in dogs and cats, the MTL proposed by the $\mathrm{FDA}^{59}$ was the V MTL for the mammal known to be more sensitive to this element, divided by 10 (safety factor). Therefore, it is possible that dogs and cats are less sensitive and, in this case, a smaller portion of the samples would have exceeded the MTL. No food exceeded the V MTL for the most sensitive mammal $(10 \mathrm{mg} / \mathrm{kg})$ in the present study.

The highest toxic metals concentrations, in general, in animal-based ingredients than plant-based ingredients could be attributed to the potential for the accumulation of these elements in the animal organism. According to $\mathrm{NRC}^{60}$, some elements can accumulate in animal tissues, such as bone tissue, skeletal muscle, liver, kidneys, and spleen, as well as in animal products such as milk, reaching critical concentrations that may imply adverse effects on the health of human beings who consumes these products. Also according to $\mathrm{NRC}^{60}$, this could happen even in situations in which the levels of these minerals in animal feed are below the MTL for the respective species (considered safe). Therefore, it is possible that food animals, such as broilers and beef cattle, consume a diet with plant-based ingredients contaminated with toxic metals in addition to supplements with a large contamination potential, such as dicalcium phosphate, and accumulate these metals in various body tissues, which results in high contamination of their by-products, such as poultry by-products meal and meat meal. The animal tissues 
mentioned above are part of the composition, in general, of animal-based ingredients used in the formulation of pet foods, which perhaps justifies the greater contamination of these by-products.

\section{Conclusion}

The analyzed foods presented high concentrations of the following elements: $\mathrm{Al}, \mathrm{Cu}, \mathrm{Hg}, \mathrm{Pb}, \mathrm{U}, \mathrm{V}$, and $\mathrm{Zn}$. In general, animal-based ingredients have a greater potential for contamination than plant-based ingredients. Further studies are needed to assess the effects of chronic ingestion of the elements mentioned above in the quantities found in this study and if under the same circumstances, these toxic metals pose risks to the dogs' and cats' health. Regarding the concentrations of the elements $\mathrm{As}, \mathrm{B}, \mathrm{Ba}, \mathrm{Be}, \mathrm{Cd}, \mathrm{Co}, \mathrm{Sn}, \mathrm{Sb}, \mathrm{Ni}$, and $\mathrm{Fe}$, in general, values above the respective MTLs and/or legal limits were not observed, both in commercial foods and in the ingredients analyzed in the present study, so it is not considered that there are intoxication risks with these elements in small animals through long-term consumption of the analyzed foods. It is noteworthy that it is necessary to establish legal limits for all metals with toxic potential.

\section{Data availability}

The datasets generated during and/or analyzed in the current study are available from the corresponding author on reasonable request.

Received: 10 August 2021; Accepted: 7 October 2021

Published online: 25 October 2021

\section{References}

1. Islam, M. S., Hossain, M. B., Matin, A. \& Sarker, M. S. I. Assessment of heavy metal pollution, distribution and source apportionment in the sediment from Feni River estuary, Bangladesh. Chemosphere 202, 25-32. https://doi.org/10.1016/j.chemosphere.2018. 03.077 (2018).

2. Ahmed, A. S. et al. Bioaccumulation of heavy metals in some commercially important fishes from a tropical river estuary suggests higher potential health risk in children than adults. PLoS ONE 14(10), e0219336. https://doi.org/10.1371/journal.pone.0219336 (2019).

3. UNEP. Document Repository - Global Mercury Assessment. https://wedocs.unep.org/20.500.11822/12297. (Accessed 30 November 2020). (2002).

4. Bampidis, V. A., Nistor, E. \& Nitas, D. Arsenic, cadmium, lead and mercury as undesirable substances in animal feeds. Sci. Papers Anim. Sci. Biotechnol. 46(1), 17-22 (2013).

5. Farzin, L., Shamsipur, M. \& Sheibani, S. A review: Aptamer-based analytical strategies using the nanomaterials for environmental and human monitoring of toxic heavy metals. Talanta 174, 619-627. https://doi.org/10.1016/j.talanta.2017.06.066 (2017).

6. Rahman, Z. \& Singh, V. P. The relative impact of toxic heavy metals (THMs) (arsenic (As), cadmium (Cd), chromium (Cr)(VI), mercury $(\mathrm{Hg})$, and lead $(\mathrm{Pb})$ on the total environment: an overview. Environ. Monit. Assess. 191(7), 1-21. https://doi.org/10.1007/ s10661-019-7528-7 (2019).

7. Hossain, M. B., Ahmed, A. S. S. \& Sarker, M. S. I. Human health risks of Hg, As, Mn, and Cr through consumption of fish, Ticto barb (Puntius ticto) from a tropical river, Bangladesh. Environ. Sci. Pollut. Res. 25, 31727-31736. https://doi.org/10.1007/s11356018-3158-9 (2018).

8. Aitio, A., Bernard, A., Fowler, B. A. \& Nordberg, G. F. Biological monitoring and biomarkers. In Handbook on the Toxicology of Metals 3rd edn (eds Nordberg, G. F. et al.) 65-78 (Elsevier, 2007).

9. Altundag, H. \& Tuzen, M. Comparison of dry, wet and microwave digestion methods for the multi element determination in some dried fruit samples by ICP-OES. Food Chem. Toxicol. 49(11), 2800-2807. https://doi.org/10.1016/j.fct.2011.07.064 (2011).

10. Cheng, J. et al. Concentrations and human health implications of heavy metals in market foods from a Chinese coal-mining city. Environ. Toxicol. Pharmacol. 50,37-44. https://doi.org/10.1016/j.etap.2017.01.011 (2017).

11. Castro-González, M. I. \& Méndez-Armenta, M. Heavy metals: Implications associated to fish consumption. Environ. Toxicol. Pharm. 26, 263-271. https://doi.org/10.1016/j.etap.2008.06.001 (2008).

12. Yang, Q. W., Xu, Y., Liu, S. J., He, J. F. \& Long, F. Y. Concentration and potential health risk of heavy metals in market vegetables in Chongqing, China. Ecotoxicol. Environ. Saf. 74, 1664-1669. https://doi.org/10.1016/j.ecoenv.2011.05.006 (2011).

13. Fang, Y. et al. Concentration and health risk evaluation of heavy metals in market-sold vegetables and fishes based on questionnaires in Beijing, China. Environ. Sci. Pollut. Res. 21, 11401-11408. https://doi.org/10.1007/s11356-014-3127-x (2014).

14. Islam, M. S., Ahmed, M. K., Habibullah-Al-Mamun, M. \& Masunaga, S. Assessment of trace metals in fish species of urban rivers in Bangladesh andhealth implications. Environ. Toxicol. Pharm. 39, 347-357. https://doi.org/10.1016/j.etap.2014.12.009 (2015).

15. Cheng, J. L., Zhang, X. H. \& Tang, Z. W. Contamination and health risk of heavymetals in vegetables from coal mining area in Huainan. J. Environ. Health 33, 127-130. https://doi.org/10.16241/j.cnki.1001-5914.2016.02.010 (2016).

16. Gu, Y.-G., Huang, H.-H. \& Lin, Q. Concentrations and human health implications of heavy metals in wild aquatic organisms captured from the corearea of Daya Bay's Fishery Resource Reserve, South China Sea. Environ. Toxicol. Pharm. 45, 90-94. https:// doi.org/10.1016/j.etap.2016.05.022 (2016).

17. Pan, X. D., Wu, P. G. \& Jiang, X. G. Levels and potential health risk of heavymetals in marketed vegetables in Zhejiang, China. Sci. Rep. 6, 20317. https://doi.org/10.1038/srep20317 (2016).

18. Zhou, T. et al. Concentrations of arsenic, cadmium and lead in human hair and typical foods in eleven Chinese cities. Environ. Toxicol. Pharmacol. 48, 150-156. https://doi.org/10.1016/j.etap.2016.10.010 (2016).

19. Darwish, W. S., Atia, A. S., Khedr, M. H. \& Eldin, W. F. S. Metal contamination in quail meat: Residues, sources, molecular biomarkers, and human health risk assessment. Environ. Sci. Pollut. Res. 25(20), 20106-20115. https://doi.org/10.1007/s11356-018-2182-0 (2018).

20. Hashemi, M. Heavy metal concentrations in bovine tissues (muscle, liver and kidney) and their relationship with heavy metal contents in consumed feed. Ecotoxicol. Environ. Saf. 154, 263-267. https://doi.org/10.1016/j.ecoenv.2018.02.058 (2018).

21. Park, S. H., Lee, M. H. \& Kim, S. K. Studies on Cd, Pb, Hg and Cr values in dog hairs from urban Korea. Asian Aust. J. Anim. Sci. 18, 1135-1140. https://doi.org/10.5713/ajas.2005.1135 (2005).

22. Tomza-Marciniak, A., Pilarczyk, B., Bąkowska, M., Ligocki, M. \& Gaik, M. Lead, cadmium and other metals in serum of pet dogs from an urban area of NW Poland. Biol. Trace Elem. Res. 149, 345-351. https://doi.org/10.1007/s12011-012-9433-6 (2012).

23. Hansen, J. C. \& Danscher, G. Quantitative and qualitative distribution of mercury in organs from arctic sledgedogs: An atomic absorption spectrophotometric and histochemical study of tissue samples from natural long-termed high dietary organic mercuryexposed dogs from Thule, Greenland. Pharmacol. Toxicol. 77, 189-195. https://doi.org/10.1111/j.1600-0773.1995.tb01011.x (1995). 
24. Sakai, T., Ito, M., Aoki, H., Aimi, K. \& Nitaya, R. Hair mercury concentrations in cats and dogs in Central Japan. Br. Vet. J. 151, 215-219. https://doi.org/10.1016/S0007-1935(95)80013-1 (1995).

25. Dunlap, K. L., Reynolds, A. J., Bowers, P. M. \& Duffy, L. K. Hair analysis in sled dogs (Canis lupus familiaris) illustrates a linkage of mercury exposure along the Yukon River with human subsistence food systems. Sci. Total Environ. 385(1-3), 80-85. https:// doi.org/10.1016/j.scitotenv.2007.07.002 (2007).

26. Sousa, A. C. et al. Mercury, pets' and hair: baseline survey of a priority environmental pollutant using a noninvasive matrix in man's best friend. Ecotoxicology 22, 1435-1442. https://doi.org/10.1007/s10646-013-1130-5 (2013).

27. López-Alonso, M. et al. Use of dogs as indicators of metal exposure in rural and urban habitats in NW Spain. Sci. Total Environ. 372, 668-675. https://doi.org/10.1016/j.scitotenv.2006.10.003 (2007).

28. Serpe, F. P. et al. Levels of heavy metals in liver and kidney of dogs from urban environment. Open Vet. J. 2, 15-18 (2012).

29. Lanocha, N., Kalisinska, E., Kosik-Bogacka, D. I. \& Budis, H. Evaluation of dog bones in the indirect assessment of environmental contamination with trace elements. Biol. Trace Elem. Res. 147, 103-112. https://doi.org/10.1007/s12011-011-9315-3 (2012).

30. Rahman, M. A., Rahman, M. M., Reichman, S. M., Lim, R. P. \& Naidu, R. Heavy metals in Australian grown and imported rice and vegetables on sale in Australia: Health hazard. Ecotoxicol. Environ. Saf. 100, 53-60. https://doi.org/10.1016/j.ecoenv.2013.11. 024 (2014).

31. Nawab, J. et al. Contamination of soil, medicinal, and fodder plants with lead and cadmium present in mine-affected areas, northern Pakistan. Environ. Model Assess. 187(9), 1-14. https://doi.org/10.1007/s10661-015-4807-9 (2015).

32. Pan, X. D., Wu, P. G. \& Jiang, X. G. Levels and potential health risk of heavy metals in marketed vegetables in Zhejiang, China. Sci. Rep. 6(1), 1-7. https://doi.org/10.1038/srep20317 (2016).

33. Nawab, J., Farooqi, S., Xiaoping, W., Khan, S. \& Khan, A. Levels, dietary intake, and health risk of potentially toxic metals in vegetables, fruits, and cereal crops in Pakistan. Environ. Sci. Pollut. Res. 25(6), 5558-5571. https://doi.org/10.1007/s11356-017-0764-x (2018).

34. INSTITUTO PET BRASIL. Censo Pet: 139.3 milhões de animais de estimação no Brasil. http://institutopetbrasil.com/imprensa/ censo-pet-1393-milhoes-de-animais-de-estimacao-no-brasil/. (Accessed 12 November 2019). (2019).

35. IBGE. Instituto Brasileiro de Geografia e Estatística. Pesquisa Nacional de Saúde. https://www.ibge.gov.br/home/estatistica/popul acao/pns/2013_vol3/default.Shtm. (Accessed 31 October 2019). (2013).

36. ABINPET. Associação Brasileira da Indústria de Produtos para Animais de Estimação. http://abinpet.org.br/mercado/. (Accessed 30 November 2020). (2019).

37. Rumbeiha, W. \& Morrison, J. A review or class I and class II pet food recalls involving chemical contaminants from 1996 to 2008. J. Med. Toxicol. 7(1), 60-66. https://doi.org/10.1007/s13181-010-0123-5 (2011).

38. Fernandes, E. A. D. N., Elias, C., Bacchi, M. A. \& Bode, P. Trace element measurement for assessment of dog food safety. Environ. Sci. Pollut. Res. 25, 2045-2050. https://doi.org/10.1007/s11356-017-8541-4 (2018).

39. Martisen, N. \& Casper, J. Allergies and elemental minerals: A new understanding. Dogs Naturally. 4, 56-59 (2013).

40. Duran, A., Tuzen, M. \& Soylak, M. Trace element concentrations of some pet foods commercially available in Turkey. Food Chem. Toxicol. 48, 2833-2837. https://doi.org/10.1016/j.fct.2010.07.014 (2010).

41. Elias, C., De Nadai Fernandes, E. \& Bacchi, M. Neutron activation analysis for assessing chemical composition of dry dog foods. J. Radioanal. Nucl. Chem. 291, 245-250. https://doi.org/10.1007/s10967-011-1285-6 (2011).

42. Luippold, A. \& Gustin, M. S. Mercury concentrations in wet and dry cat and dog food. Anim. Feed Sci. Technol. 222, 190-193. https://doi.org/10.1016/j.anifeedsci.2016.10.021 (2016).

43. Davies, M. et al. Mineral analysis of complete dog and cat foods in the UK and compliance with European guidelines. Sci. Rep. 7(1), 1-9. https://doi.org/10.1038/s41598-017-17159-7 (2017).

44. Kim, H. T., Loftus, J. P., Mann, S. \& Wakshlag, J. J. Evaluation of arsenic, cadmium, lead and mercury contamination in over-thecounter available dry dog foods with different animal ingredients (red meat, poultry, and fish). Front. Vet. Sci. 5, 264. https://doi. org/10.3389/fvets.2018.00264 (2018).

45. da Costa, S. S. L. et al. Multivariate optimization of an analytical method for the analysis of dog and cat foods by ICP OES. Talanta 108, 157-164. https://doi.org/10.1016/j.talanta.2013.03.002 (2013).

46. Paulelli, A. C. C. et al. Risk assessment of 22 chemical elements in dry and canned pet foods. J. Consum. Protect. Food Saf. 13, 359-365. https://doi.org/10.1007/s00003-018-1178-5 (2018).

47. Granados-Chinchilla, F., Mena, S. P. \& Arias, L. M. Inorganic contaminants and composition analysis of commercial feed grade mineral compounds available in Costa Rica. Int. J. Food Contamination. 2(1), 1-14. https://doi.org/10.1186/s40550-015-0015-1 (2015).

48. Post, L. O. et al. Risk assessment of copper and molybdenum and other minerals in feed ingredients and finished feeds. J. Regulat. Sci. 7, 1-9 (2019).

49. Adamse, P., Van der Fels-Klerx, H. J. \& de Jong, J. Cadmium, lead, mercury and arsenic in animal feed and feed materials-trend analysis of monitoring results. Food Additives Contaminants Part A 34(8), 1298-1311 (2017).

50. Zook, B. C. The pathologic anatomy of lead poisoning in dogs. Vet. Pathol. 9, 310-327. https://doi.org/10.1177/030098587200900 $503(1972)$

51. Berny, P. J., Cote, L. M. \& Buck, W. B. Case reports of lead poisoning in dogs from the National Animal Poison Control Center and the Centre National D'Informations Toxicologiques, Veterinaires: Anecdotes or reality?. Vet. Hum. Toxicol. 34, 26-31 (1992).

52. Høgåsen, H. R., Ørnsrud, R., Knutsen, H. K. \& Bernhoft, A. Lead intoxication in dogs: risk assessment of feeding dogs trimmings of lead-shot game. BMC Vet. Res. 12(1), 1-8. https://doi.org/10.1186/s12917-016-0771-z (2016).

53. Canfield, P. J., Fairburn, A. J. \& Watson, A. D. Blood lead, urinary delta aminolevulinic acid and the diagnosis of lead poisoning in dogs. Aust. Vet. J. 61, 323-324. https://doi.org/10.1111/j.1751-0813.1984.tb07139.x (1984).

54. Huerter, L. Lead toxicosis in a puppy. Can. Vet. J. 41(7), 565 (2000).

55. AOAC. Official Methods of Analysis (AOAC International, 2006).

56. Association of Official Analytical Chemists [AOAC]. Official Methods of Analysis 16th edn. (AOAC, 1995).

57. Pedrinelli, V. et al. Concentrations of macronutrients, minerals and heavy metals in home-prepared diets for adult dogs and cats. Sci. Rep. 9, 1-12. https://doi.org/10.1038/s41598-019-49087-z (2019).

58. Llorent-Martínez, E. J., Ortega-Barrales, P., Fernández-de Córdova, M. L., Domínguez-Vidal, A. R. M. A. \& Ruiz-Medina, A. Investigation by ICP-MS of trace element levels in vegetable edible oils produced in Spain. Food Chem. 127(3), 1257-1262. https:// doi.org/10.1016/j.foodchem.2011.01.064 (2011).

59. FDA. Target Animal Safety Review Memorandum. U. S. Food and Drug Administration-Center for Veterinary Medicine. https:// www.fda.gov/media/81895/download. (Accessed 12 November 2019). (2011).

60. NRC. Mineral Tolerance of Animals (National Academies Press, 2005).

61. FEDIAF. Nutritional Guidelines for Complete and Complementary Pet Food for Cats and Dogs (Fédération Européenne de l'Industrie des Aliments pour Animaux Familiers, 2020).

62. National Research Council et al. Nutrient Requirements of Dogs and Cats (National Academies Press, 2006).

63. Berthon, G. Aluminium speciation in relation to aluminium bioavailability, metabolism and toxicity. Coord. Chem. Rev. 228, 319-341. https://doi.org/10.1016/S0010-8545(02)00021-8 (2002).

64. Slanina, P. et al. Dietary citric acid enhances absorption of aluminum in antacids. Clin. Chem. 32, 539-541. https://doi.org/10. 1093/clinchem/32.3.539 (1986). 
65. Ecelbarger, C. A. \& Greger, J. L. Dietary citrate and kidney function affect aluminum, zinc and iron utilization in rats. J. Nutr. 121, 1755-1762. https://doi.org/10.1093/jn/121.11.1755 (1991).

66. Greger, J. L. \& Powers, C. F. Assessment of exposure to parenteral and oral aluminum with and without citrate using a desferrioxamine test in rats. Toxicology 76, 119-132. https://doi.org/10.1016/0300-483X(92)90159-C (1992).

67. Ecelbarger, C. A., MacNeil, G. G. \& Greger, J. L. Tissue aluminum accumulation and toxic consequences in rats chronically fed aluminum with and without citrate. J. Agric. Food Chem. 42, 2220-2224. https://doi.org/10.1021/jf00046a027 (1994).

68. Owen, L. M. W., Crews, H. M., Bishop, N. J. \& Massey, R. C. Aluminium uptake from some foods by guinea pigs and the characterization of aluminium in in vivo intestinal digesta by SEC-ICP-MS. Food Chem. Toxicol. 32, 697-705. https://doi.org/10.1016/ S0278-6915(09)80002-1 (1994).

69. Katz, A. C., Frank, D. W., Sauerhoff, M. W., Zwicker, G. M. \& Freudenthal, R. I. A 6-month dietary toxicity study of acidic sodium aluminium phosphate in beagle dogs. Food Chem. Toxicol. 22(1), 7-9. https://doi.org/10.1016/0278-6915(84)90045-0 (1984).

70. Pettersen, J. C., Hackett, D. S., Zwicker, G. M. \& Sprague, G. L. Twenty-six week toxicity study with KASAL" (basic sodium aluminum phosphate) in beagle dogs. Environ. Geochem. Health 12, 121-123 (1990).

71. Charbonneau, S. M. et al. Chronic toxicity of methylmercury in the adult cat interim report. Toxicology 5, 337-349. https://doi. org/10.1016/0300-483X(76)90052-4 (1976).

72. Hall, B. D., Bodaly, R. A., Fudge, R. J. P., Rudd, J. W. M. \& Rosenberg, D. M. Food as the dominant pathway of methylmercury uptake by fish. Water Air Soil Pollut. 100(1), 13-24 (1997).

73. Kasper, D., Botaro, D., Palermo, E. F. A. \& Malm, O. Mercúrio em peixes-fontes e contaminação. Oecologia Brasiliensis 11, 228-239 (2007).

74. Kitahara, S. E. et al. Mercúrio total em pescado de água doce. Ciênc Tecnol. Aliment. 20, 267-273. https://doi.org/10.1590/S010120612000000200024 (2000).

75. Li, P., Feng, X. \& Qiu, G. Methylmercury exposure and health effects from rice and fish consumption: A review. Int. J. Environ. Res. Public Health 7(6), 2666-2691. https://doi.org/10.3390/ijerph7062666 (2010).

76. Dorea, J. G. Fish meal in animal feed and human exposure to persistent bioaccumulative and toxic substances. J. Food Prot. 69, 2777-2785. https://doi.org/10.4315/0362-028X-69.11.2777 (2006).

77. Dasgupta, S., Onders, R. J., Gunderson, D. T. \& Mims, S. D. Methylmercury concentrations found in wild and farm-raised paddlefish. J. Food Sci. 69, fct122-fct125. https://doi.org/10.1111/j.1365-2621.2004.tb15502.x (2004).

78. Dewailly, E., Ayotte, P., Lucas, M. \& Blanchet, C. Risk and benefits from consuming salmon and trout: A Canadian perspective. Food Chem. Toxicol. 45, 1343-1348. https://doi.org/10.1016/j.fct.2007.01.010 (2007).

79. Ginsberg, G. L. \& Toal, B. F. Quantitative approach for incorporating methylmercury risks and omega-3 fatty acid benefits in developing species-specific fish consumption advice. Environ. Health Perspect. 117, 267-275. https://doi.org/10.1289/ehp.11368 (2008).

80. Olmedo, P. et al. Determination of toxic elements (mercury, cadmium, lead, tin and arsenic) in fish and shellfish samples. Risk assessment for the consumers. Environ. Int. 59, 63-72. https://doi.org/10.1016/j.envint.2013.05.005 (2013).

81. Boscolo, W. R. et al. Farinha de resíduo da filetagem de tilapia em rações para alevinos de Piavuçú (Leporinus macrocephalus). Revista Brasileira de Zootecnia 34, 1819-1827 (2005).

82. Peixe, B. R. Anuário Peixe BR da Piscicultura 2018 (Associação Brasileira de Piscicultura, 2019).

83. Thomas, K. W., Pellizzari, E. D. O. \& Berry, M. R. Population-based dietary intakes and tap water concentrations for selected elements in the EPA region V National Human Exposure Assessment Survey (NHEXAS). J. Exposure Sci. Environ. Epidemiol. 9, 402 (1999).

84. Azar, A., Trochimowicz, H. J., Maxfield, M. E. Review of lead studies in animals carried out at Haskell Laboratory: Two-year feeding study and response to hemorrhage study. in Environmental health aspects of lead: Proceedings International Symposium. 199-210 (1973).

85. Steiss, J. E., Braund, K. G. \& Clark, E. G. Inability to experimentally produce a polyneuropathy in dogs given chronic oral low level lead. Can. J. Comp. Med. 49, 401-404 (1985).

86. Wismer, T. Lead. In Small Animal Toxicology 3rd edn (eds Peterson, M. \& Talcott, P.) 609-615 (Saunders, 2013).

87. BRASIL. Brasil possui a 5a maior reserva de urânio do mundo. http://www.brasil.gov.br/noticias/infraestrutura/2016/09/brasilpossui-5-maiorreserva-de-uranio-no-mundo. (Accessed 29 October 2019).

88. Prado, G. R. et al. Evaluation of uranium incorporation from contaminated areas using teeth as bioindicators-A case study. Radiat. Prot. Dosimetry. 130(2), 249-252. https://doi.org/10.1093/rpd/ncm 489 (2008).

89. Arruda-Neto, J. D. et al. Long-term accumulation and microdistribution of uranium in the bone and marrow of beagle dog. Int. J. Radiat. Biol. 80(8), 567-575. https://doi.org/10.1080/09553000410001723884 (2004).

90. Vicente-Vicente, L. et al. Nephrotoxicity of uranium: Pathophysiological, diagnostic and therapeutic perspectives. Toxicol. Sci. 118(2), 324-347. https://doi.org/10.1093/toxsci/kfq178 (2010).

\section{Acknowledgements}

We thank Renata Maria Consentino Conti for technical assistance, the Grandfood Ind. Ltd. team for their support in this study, and Biorigin Brazil for collaboration with laboratory activities.

\section{Author contributions}

C.F.F.P.; M.A.B.; R.S.P. and. R.V.A.Z. were responsible for planning the study. R.V.A.Z.; L.W.R.; T.H.A.V.; R.B.A.R.; M.F.R.; A.R.A.; M.P.P. and V.P. were responsible conducting the analysis, writing and editing the manuscript. R.S.P. and C.F.F.P. were responsible for manufacturing the diets and reviewing the manuscript. J.C.C.B. was responsible for the statistical analysis. M.A.B. were responsible for writing and editing the manuscript.

\section{Competing interests}

R.S.P. and C.F.F.P. are employed in Grandfood Industria e Comercio LTDA (Premier pet). Grandfood Industria e Comercio LTDA had no role in the analysis of results and participated at study design and producing diets. Other/rest of the authors do not have any competing interest to declare.

\section{Additional information}

Correspondence and requests for materials should be addressed to M.A.B.

Reprints and permissions information is available at www.nature.com/reprints.

Publisher's note Springer Nature remains neutral with regard to jurisdictional claims in published maps and institutional affiliations. 
(c) (i) Open Access This article is licensed under a Creative Commons Attribution 4.0 International cc) License, which permits use, sharing, adaptation, distribution and reproduction in any medium or format, as long as you give appropriate credit to the original author(s) and the source, provide a link to the Creative Commons licence, and indicate if changes were made. The images or other third party material in this article are included in the article's Creative Commons licence, unless indicated otherwise in a credit line to the material. If material is not included in the article's Creative Commons licence and your intended use is not permitted by statutory regulation or exceeds the permitted use, you will need to obtain permission directly from the copyright holder. To view a copy of this licence, visit http://creativecommons.org/licenses/by/4.0/.

(C) The Author(s) 2021 